WSRC-TR-2002-00432

Rev. 0

\title{
Evaluation of Evaporation Technologies for Treating Contaminated Groundwater (U)
}

Westinghouse Savannah River Company Savannah River Site
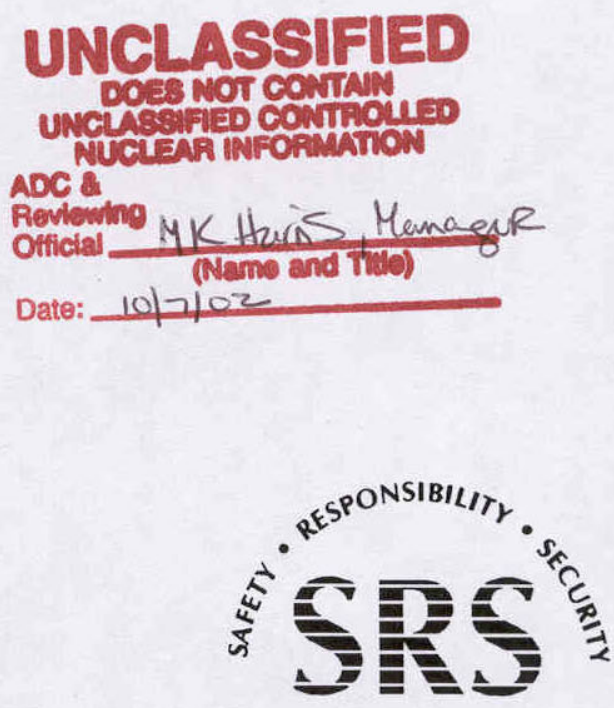
This document was prepared in conjunction with work accomplished under Contract No. DE-AC09-96SR18500 with the U. S. Department of Energy.

\section{DISCLAIMER}

This report was prepared as an account of work sponsored by an agency of the United States Government. Neither the United States Government nor any agency thereof, nor any of their employees, makes any warranty, express or implied, or assumes any legal liability or responsibility for the accuracy, completeness, or usefulness of any information, apparatus, product or process disclosed, or represents that its use would not infringe privately owned rights. Reference herein to any specific commercial product, process or service by trade name, trademark, manufacturer, or otherwise does not necessarily constitute or imply its endorsement, recommendation, or favoring by the United States Government or any agency thereof. The views and opinions of authors expressed herein do not necessarily state or reflect those of the United States Government or any agency thereof.

This report has been reproduced directly from the best available copy.

Available for sale to the public, in paper, from: U.S. Department of Commerce, National Technical Information Service, 5285 Port Royal Road, Springfield, VA 22161, phone: (800) 553-6847, fax: (703) 605-6900

email: orders@ntis.fedworld.gov

online ordering: http://www.ntis.gov/help/index.asp

Available electronically at http://www.osti.gov/bridge

Available for a processing fee to U.S. Department of Energy and its contractors, in paper, from: U.S. Department of Energy, Office of Scientific and Technical Information, P.O. Box 62, Oak Ridge, TN 37831-0062,

phone: (865)576-8401,

fax: (865)576-5728

email: $\underline{\text { reports@ adonis.osti.gov }}$ 
WSRC-TR-2002-00432

Rev. 0

\section{Evaluation of Evaporation Technologies for Treating Contaminated Groundwater (U)}

G. P. Flach

Westinghouse Savannah River Company

Savannah River Site

Aiken, SC 29808

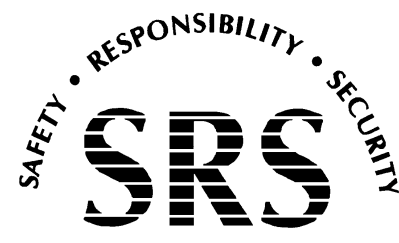

SAVANNAH RIVER SITE 
Evaluation of Evaporation Technologies for Treating Contaminated Groundwater (U)

Approvals:

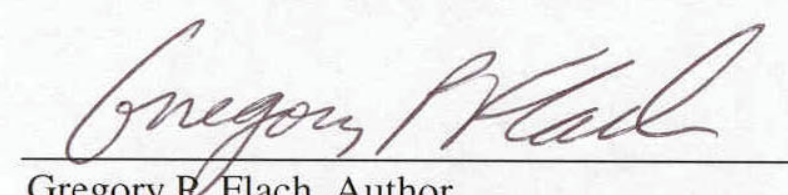

Gregory P. Flach, Author

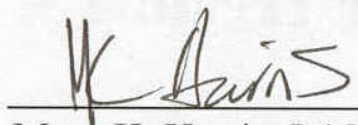

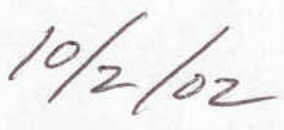

Date

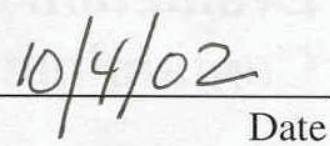




\section{Contents}

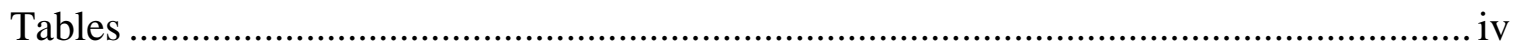

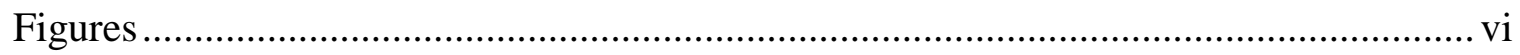

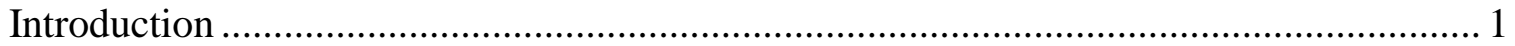

Technical analysis of evaporation technologies ....................................................... 2

Passive evaporation technologies for liquid concentration ............................................ 3

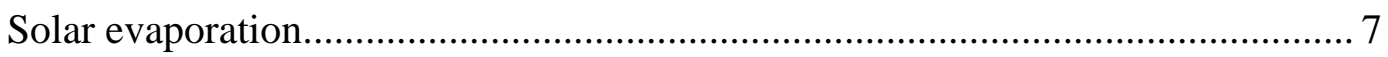

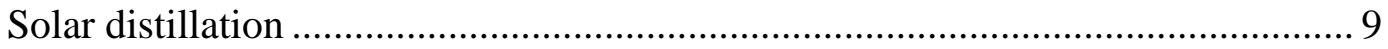

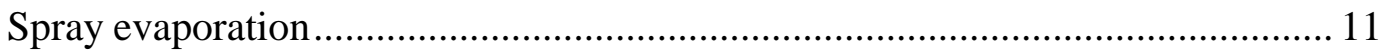

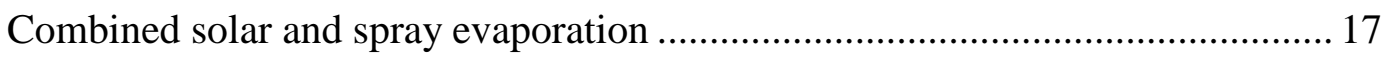

Active evaporation technologies for liquid concentration ......................................... 19

Technologies for reduction to dry solids .................................................................. 20

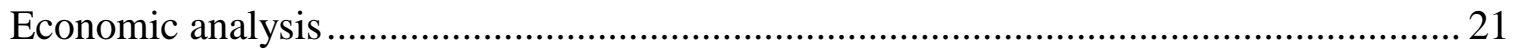

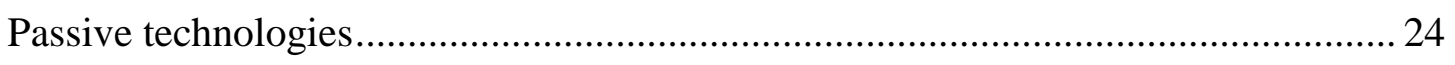

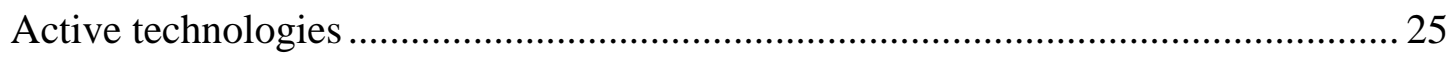

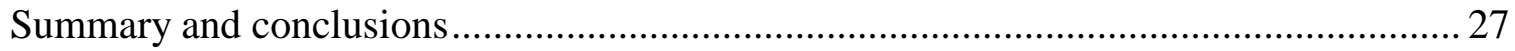

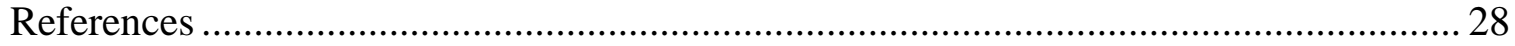




\section{Tables}

Table 1 Representative operational costs for the F- and H-area Water Treatment Units (WTUs); data courtesy of Stephani Fuller, July 19, 2002 1

Table 2 Energy and cost required to vaporize water from an initial temperature of $20^{\circ} \mathrm{C}\left(68^{\circ} \mathrm{F}\right)$ at atmospheric pressure

Table 3 Estimates of average solar insolation at or near the Savannah River Site.

Table 4 Theoretical upper bound estimate of the solar evaporation rate at the Savannah River Site

Table 5 Climate of the Savannah River Site and surroundings 5

Table 6 Adiabatic saturation calculation for average SRS conditions and a $20 \mathrm{ft}$ by $100 \mathrm{ft}$ cross-sectional area.

Table $7 \quad$ Upper limit, optimistic and pessimistic estimates of net pond evaporation at the Savannah River Site....

Table 8 Selected solar radiative properties 8

Table 9

Efficiency of solar evaporation

Table 10 Production and efficiency of solar distillation under SRS conditions

Table 11 Estimated climate at location of Snow Machines Inc. client in NE South Dakota

Table 12 Analysis of Snow Machines Inc. application in NE South Dakota

Table 13

Adiabatic saturation calculation for South Dakota conditions, a 6.1 mph wind, and a $20 \mathrm{ft}$ by $100 \mathrm{ft}$ cross-sectional area

Table 14 Adiabatic saturation calculation for average SRS conditions in January and a $20 \mathrm{ft}$ by $100 \mathrm{ft}$ cross-sectional area

Table 15 Estimated performance of an optimal conceptual design for passive evaporation of contaminated groundwater.

Table 16 Forecast real US Treasury interest rates over the past 20 years 22

Table 17

Time value of money financial formulas.

Table 18

Consumer Price Indices for 1970 through 2001

Table 19 Cost analysis for large basin-type solar distillation under SC conditions

Table 20 Partial cost analysis for an optimal solar and spray evaporation system

Table 21 Cost analysis of direct evaporation by Fulbright and others (1996)......... 26 


\section{Tables (Continued)}

Table 22 Cost analyses of Vacom and Severn Trent Services evaporation

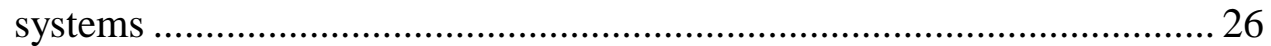

Table 23 Summary of technical and economic feasibility of evaporation technologies.............................................................................. 27 


\section{Figures}

Figure 1 Solar insolation map for the continental United States and Mexico ........... 4

Figure 2 Graphical comparison of pan and pond evaporation to rainfall ................. 8

Figure 3 Examples of small and large-scale solar distillation designs .................. 10

Figure $4 \quad$ Spray evaporation using snow-making technology modified for wastewater treatment (photos reproduced from Snow Machines Inc. website) .......................................................................... 12

Figure 5 Conceptual design of an optimal passive evaporation system ................. 18

Figure 6 Example spray dryer (reproduced from www.ionics.com) ...................... 21 


\section{Introduction}

Evaporation has occasionally been considered as a potentially viable technology for treating SRS groundwater contaminated with radionuclides and metals (e.g. Bibler, 1990; Fulbright et al., 1996). The high cost of operating the F- and H-area seepage basin chemical treatment units, compared to conventional wastewater treatment costs, has prompted renewed interest in evaporation strategies for groundwater remediation. The direct operating cost for the F- and H-area seepage basins Water Treatment Units (WTUs) including materials and labor is approximately $\$ 0.047$ per gallon treated (Table 1), or $\$ 47$ per 1000 gallons. Typical wastewater/sewage treatment costs are on the order of a few dollars per 1000 gallons.

Evaporation could be used to achieve two different endpoints. First, non-volatile solute contaminants (metals and most radionuclides) could be greatly concentrated (e.g. 100:1), and the low volume concentrate combined with other liquid radioactive wastes in the separations area for subsequent treatment and disposal. The condensate stream, comprising $99 \%$ of the feed stream, would be clean except for volatile radionuclides. These would include tritium, I-129, and Tc-99, essentially at groundwater concentrations. Thus, the bulk of the extracted groundwater could likely be irrigated rather than reinjected into the ground. Avoiding the need for up-gradient reinjection would facilitate efficient capture of the down-gradient plume. Secondly, the concentrated waste stream could be reduced to dry solids and disposed of as solid radioactive waste. Evaporation technologies could play a role in either or both processes. This study considers the technical and economic feasibility of several passive and active evaporation technologies for treatment of groundwater contaminated with radionuclides and metals.

Table 1 Representative operational costs for the F- and H-area Water Treatment Units (WTUs); data courtesy of Stephani Fuller, July 19, 2002.

\begin{tabular}{|cl|}
\hline Cost $\quad$ Units & Item \\
\hline $0.0460 \$$ gal & low of range \\
\hline $0.0770 \$ /$ gal & high of range \\
\hline $0.0615 \$ /$ gal & average total cost \\
\hline 1.1394 & Essential Site Services (ESS) factor \\
\hline 1.1497 & General and Administrative $(G \& A)$ factor \\
\hline 1.310 & overhead factor (ESS $\times$ G\&A) \\
\hline $0.047 \$ /$ gal & direct operating cost, including labor \\
\hline
\end{tabular}




\section{Technical analysis of evaporation technologies}

Evaporation is an energy intensive process, due to the large heat of vaporization of water (Table 2). For example, the total energy required to warm and then vaporize groundwater initially at $20^{\circ} \mathrm{C}$ is approximately $2.7 \mathrm{~kW}-\mathrm{hr} / \mathrm{gal}$ or $9300 \mathrm{BTU} / \mathrm{gal}$ at atmospheric pressure. The heat of vaporization comprises $87 \%$ of the total energy. Were the energy supplied by natural gas purchased at current rates, the fuel cost alone for direct evaporative heating would be about $\$ 0.056$ per gallon. This amount exceeds current costs for the F- and H-area WTUs (Table 1). So, energy costs must be significantly reduced in order for evaporation to be a viable alternative to the WTUs, and other applications in general.

Energy costs can be greatly reduced by utilizing a "free" source energy such as solar heating, sensible heat in low-humidity wind, or waste heat from another process. Alternatively, energy can be used more efficiently through the use of "multiple-effects", and heat pump technologies such as Mechanical Vapor Recompression (MVR). Both approaches offer substantially lower total (capital + operating) costs, and make evaporation a potentially viable alternative to the F- and H-area WTUs.

In the sections that follow, several passive and active technologies for concentrating contaminated groundwater through evaporation are analyzed in more detail for technical merit. In the context of this report, "passive" means the energy source used to vaporize water comes from a natural source, such as solar insolation or wind. "Active" refers to an engineered source of energy, such as fossil fuel or nuclear power. Finally, techniques for drying a concentrated liquid waste stream to produce a solid waste are considered.

Table 2 Energy and cost required to vaporize water from an initial temperature of $20^{\circ} \mathrm{C}\left(68^{\circ} \mathrm{F}\right)$ at atmospheric pressure.

\begin{tabular}{|lrcc|}
\hline Parameter & Symbol & Sl units & English units \\
\hline Groundwater temperature & $\mathrm{T}_{\mathrm{GW}}$ & $20 \mathrm{C}$ & $68 \mathrm{~F}$ \\
\hline Boiling temperature at 1 atm & $\mathrm{T}_{\mathrm{boil}}$ & $100 \mathrm{C}$ & $212 \mathrm{~F}$ \\
\hline Specific heat & $\mathrm{c}_{\mathrm{p}}$ & $4.216 \mathrm{~kJ} / \mathrm{kg}-\mathrm{K}$ & $1.007 \mathrm{BTU} / \mathrm{lbm}-\mathrm{R}$ \\
\hline Heat of vaporization & $\mathrm{h}_{\mathrm{fg}}$ & $2257 \mathrm{~kJ} / \mathrm{kg}$ & $970.4 \mathrm{BTU} / \mathrm{lbm}$ \\
\hline Enthalpy required to boil GW & $\Delta \mathrm{h}$ & $2594 \mathrm{~kJ}$ & $1115 \mathrm{BTU}$ \\
\hline Ratio & $\mathrm{h}_{\mathrm{fg}} / \Delta \mathrm{h}$ & $87 \%$ & $87 \%$ \\
\hline Density @ 20C & $\rho_{\mathrm{f}}$ & $998 \mathrm{~kg} / \mathrm{m}^{3}$ & $62.3 \mathrm{lbm} / \mathrm{ft}^{3}$ \\
\hline Enthalpy per unit volume & $\rho_{\mathrm{f}} \Delta \mathrm{h}$ & $2.59 \mathrm{E}+06 \mathrm{~kJ} / \mathrm{m}^{3}$ & $6.95 \mathrm{E}+04 \mathrm{BTU} / \mathrm{ft}^{3}$ \\
\hline & & $2.72 \mathrm{~kW}-\mathrm{hr} / \mathrm{gal}$ & $9290 \mathrm{BTU} / \mathrm{gal}$ \\
\hline Energy cost & & & $0.6 \$ / \mathrm{therm}$ \\
\hline & & $0.0205 \$ / \mathrm{kW}-\mathrm{hr}$ & $0.000006 \$ / \mathrm{BTU}$ \\
\hline Evaporation cost & & $0.056 \$ / \mathrm{gal}$ & $0.056 \$ / \mathrm{gal}$ \\
\hline
\end{tabular}




\section{Passive evaporation technologies for liquid concentration}

Solar radiation or "insolation" is a natural source of energy that can supply part or all of the energy required to evaporate water. An inherent limitation of solar heating concepts is the relatively low power density of solar insolation. Figure 1 shows a map of annual average solar insolation in $\mathrm{kW}-\mathrm{hr} / \mathrm{m}^{2}$-day for the continental United States and Mexico. At the Savannah River Site, solar insolation averages about $4.5 \mathrm{~kW}-\mathrm{hr} / \mathrm{m}^{2}$-day (Table 3). To put this number in perspective, suppose all solar radiation goes towards vaporizing water initially at $100^{\circ} \mathrm{C}$. This is an unrealistic scenario that provides a convenient upper bound on the evaporation rate that could be achieved with solar heating. As shown in Table 4, a large area is required for solar evaporation, at least 5.6 acres per gpm to be evaporated. Solar evaporation can be technically feasible if sufficient land is available.

Another natural source of energy is the sensible heat that can be extracted from low $(<100 \%)$ humidity air through evaporative cooling. The climate of South Carolina is somewhat humid (Table 5), which is obviously not conducive to evaporation. Nevertheless, wind can naturally deliver large volumes of air to an evaporation facility and make evaporative cooling a potentially viable technology from a technical standpoint. For example, if air at average SRS conditions $\left(64^{\circ} \mathrm{F}, 68 \%\right.$ humidity) is delivered by an average wind $(6.1 \mathrm{mph})$ through a $20 \mathrm{ft}$ high by $100 \mathrm{ft}$ wide cross-sectional area and brought to $100 \%$ humidity through evaporative cooling, then $14 \mathrm{gpm}$ would be evaporated (Table 6).

Passive evaporation technologies typically use both solar heating and evaporative cooling in varying proportions. For example, an evaporation pond will be warmed by solar radiation, and extract sensible heat from unsaturated air blowing over the pond surface. In the sections below, solar evaporation, solar distillation, spray evaporation, and combined solar and spray evaporation are further analyzed from a technical feasibility standpoint. 


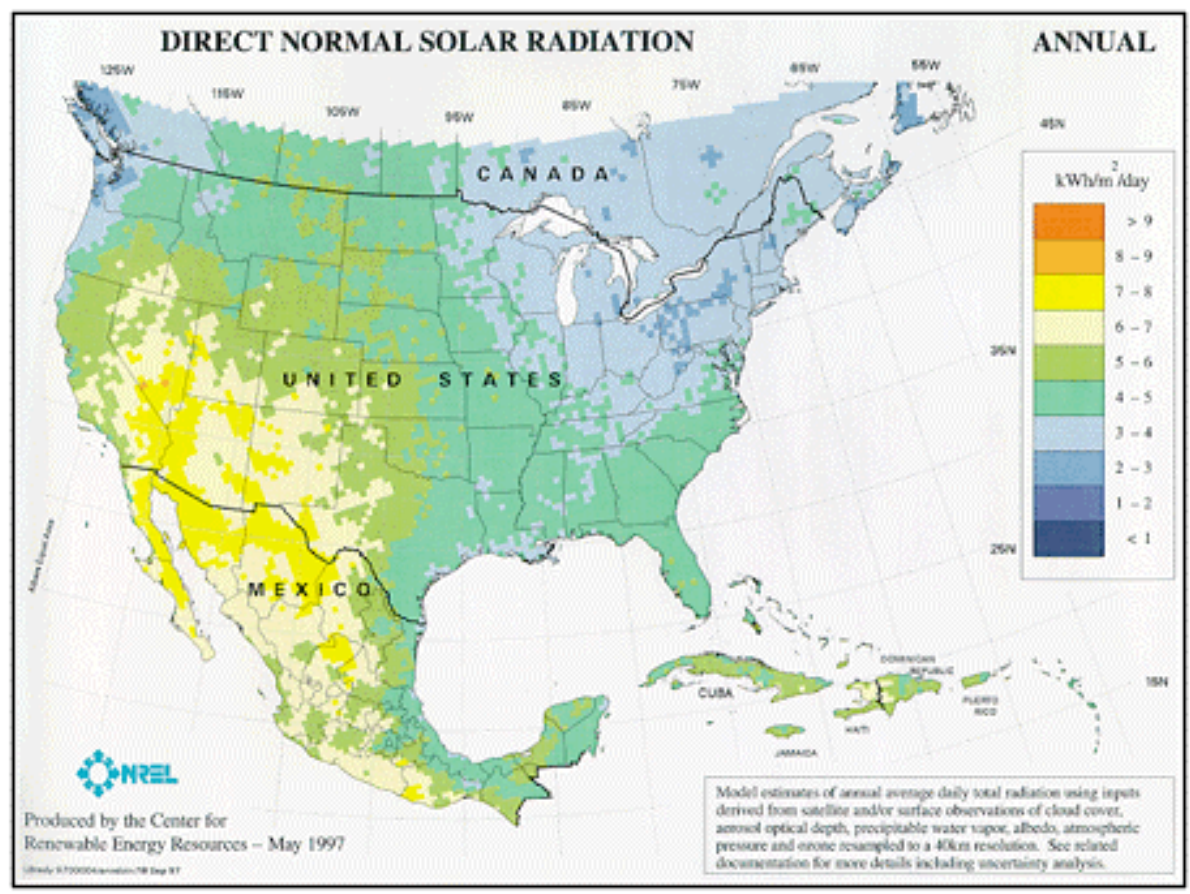

Figure 1 Solar insolation map for the continental United States and Mexico.

Table 3 Estimates of average solar insolation at or near the Savannah River Site.

\begin{tabular}{|c|c|c|c|c|}
\hline \multicolumn{3}{|c|}{$\begin{array}{c}\text { Krieth \& } \\
\text { Kreider (1978) }\end{array}$} & \multirow[b]{2}{*}{ SRS $1995^{3}$} & \multirow[b]{2}{*}{ SRS $1996^{4}$} \\
\hline units & 1 & Focus Solar $^{2}$ & & \\
\hline ly/d & 400 & & 372 & 388 \\
\hline $\mathrm{kW}-\mathrm{hr} / \mathrm{m}^{2}-\mathrm{d}$ & 4.6 & 4.6 & 4.3 & 4.5 \\
\hline BTU/hr-ft ${ }^{2}$ & 61 & 61 & 57 & 59 \\
\hline BTU/d-ft ${ }^{2}$ & 1471 & 1459 & 1368 & 1427 \\
\hline $\mathrm{W} / \mathrm{m}^{2}$ & 193 & 192 & 180 & 188 \\
\hline
\end{tabular}

\footnotetext{
1 Figure 2.24 and Table A2.4 (Charleston)

2 www.focus-solar.com/insolation_levels_us.htm

${ }^{3}$ WSRC-TR-96-0309

${ }^{4}$ WSRC-TR-97-0214
} 
Table 4 Theoretical upper bound estimate of the solar evaporation rate at the Savannah River Site.

\begin{tabular}{|ccc|}
\hline & Metric & English \\
\hline $\begin{array}{r}\text { Energy flux } \\
\begin{array}{c}\text { Heat of } \\
\text { vaporization }\end{array}\end{array}$ & $4.5 \mathrm{~kW}-\mathrm{hr} / \mathrm{m}^{2}-\mathrm{d}$ & $59 \mathrm{BTU} / \mathrm{hr}^{-\mathrm{ft}^{2}}$ \\
\hline $\begin{array}{r}\text { Water density } \\
\text { Evaporation } \\
\text { rates }\end{array}$ & $2257 \mathrm{~kJ} / \mathrm{kg}$ & $970 \mathrm{BTU} / \mathrm{lbm}$ \\
\hline & $958 \mathrm{~kg} / \mathrm{m}^{3}$ & $60 \mathrm{lbm} / \mathrm{ft}^{3}$ \\
\hline & $2.74 \mathrm{E}-08 \mathrm{~m} / \mathrm{s}$ & $1.02 \mathrm{E}-03 \mathrm{ft} / \mathrm{hr}$ \\
\hline & $5.56 \mathrm{gpm} / \mathrm{acre}$ & $67 \mathrm{gal} / \mathrm{ft}^{2}-\mathrm{yr}$ \\
\hline & $108 \mathrm{in} / \mathrm{yr}$ & $5.56 \mathrm{gpm} / \mathrm{acre}$ \\
\hline & $0.18 \mathrm{gal} / \mathrm{ft}^{2}-\mathrm{d}$ & $108 \mathrm{in} / \mathrm{yr}$ \\
\hline & $1.98 \mathrm{gal} / \mathrm{m}^{2}-\mathrm{d}$ & $0.18 \mathrm{gal} / \mathrm{ft}^{2}-\mathrm{d}$ \\
\hline
\end{tabular}

Table 5 Climate of the Savannah River Site and surroundings.

\begin{tabular}{|rccc|}
\hline $\begin{array}{c}\text { Annual/ average } \\
\text { climate data }\end{array}$ & $\begin{array}{c}\text { SC State } \\
\text { Climatology } \\
\text { Office }\end{array}$ & $\begin{array}{c}\text { Aiken 4 NE } \\
\text { station }\end{array}$ & $\begin{array}{c}\text { SRS Weather } \\
\text { Center }\end{array}$ \\
\hline Temperature (F) & 64 & 64.0 & 64.7 \\
\hline Precipitation (in/yr) & 48 & 49.66 & 51.1 \\
\hline Humidity & & & $68 \%$ \\
\hline Wind speed (mph) & 8 & & 6.1 \\
\hline Pan evaporation (in/yr) & 57 & & \\
\hline
\end{tabular}


Table 6 Adiabatic saturation calculation for average SRS conditions and a $20 \mathrm{ft}$ by $100 \mathrm{ft}$ cross-sectional area.

\begin{tabular}{|c|c|c|c|c|c|}
\hline \multicolumn{6}{|c|}{ Adiabatic saturation / swamp cooler calculation using ASHRAE (1985) equations } \\
\hline \multirow{2}{*}{\begin{tabular}{|c|} 
Constants \\
univ. gas const. \\
\end{tabular}} & & & & \multicolumn{2}{|r|}{ source } \\
\hline & $R$ & \multicolumn{2}{|c|}{$1545.33 \mathrm{ft}-\mathrm{lbf} /(\mathrm{lbmole}-\mathrm{R})$} & & \\
\hline molecular wt. air & $M_{a}$ & \multicolumn{2}{|l|}{$28.9645 \mathrm{lbm} / \mathrm{lbmole}$} & \multicolumn{2}{|r|}{ from eqn (24) } \\
\hline air gas constant & $\mathrm{R}_{\mathrm{a}}$ & \multicolumn{2}{|l|}{$53.35 \mathrm{ft}-\mathrm{lbf} /(\mathrm{lbm}-\mathrm{R})$} & & \\
\hline \multicolumn{6}{|l|}{ Incoming air stream } \\
\hline pressure & $\mathrm{p}$ & \multicolumn{2}{|l|}{14.7 psia } & & \\
\hline temperature & $t$ & $64 \mathrm{~F}$ & $17.8 \mathrm{C}$ & $523.67 \mathrm{R}$ & SRS conditions \\
\hline relative humidity & $\phi$ & \multicolumn{2}{|l|}{0.68 unitless } & & \\
\hline sat. pressure & $p_{w s}$ & \multicolumn{2}{|l|}{0.2991 psia } & & eqn (4) \\
\hline water vap. pres. & $\mathrm{p}_{\mathrm{w}}$ & \multicolumn{2}{|l|}{0.2034 psia } & & eqn (22) \\
\hline humidity ratio & $\mathrm{W}, \gamma$ & 0.008725 unitless & \multirow[t]{2}{*}{61.07 grains $/ \mathrm{bm}_{\mathrm{a}}$} & \multicolumn{2}{|r|}{ eqn (20) } \\
\hline sat. humidity ratio & $\mathrm{W}_{\mathrm{s}}$ & 0.012916 unitless & & \multicolumn{2}{|r|}{ eqn (21) } \\
\hline deg. of saturation & $\mu$ & \multicolumn{2}{|l|}{0.6755 unitless } & \multicolumn{2}{|r|}{ eqn (10) } \\
\hline specific volume & $v$ & \multicolumn{2}{|l|}{$13.38 \mathrm{ft}^{3} / \mathrm{lbm}_{\mathrm{a}}$} & \multicolumn{2}{|r|}{ eqn (26) } \\
\hline & & \multicolumn{2}{|l|}{$13.27 \mathrm{ft}^{3} / \mathrm{lbm}$} & \multicolumn{2}{|r|}{ using $(1+\gamma)$ factor and eqn (26) } \\
\hline & & $13.20 \mathrm{ft}^{3} / / \mathrm{lbm}$ & & & using ideal gas law \\
\hline specific enthalpy & $\mathrm{h}$ & $24.87 \mathrm{BTU} / \mathrm{lbm}_{\mathrm{a}}$ & & & eqn (30) \\
\hline Outgoing for adiaba & atic sature & on/evaporation & & & \\
\hline pressure & $\mathrm{p}$ & $14.7 \mathrm{psia}$ & & & \\
\hline temperature & $t$ & $57.46 \mathrm{~F}$ & $14.1 \mathrm{C}$ & $517.13 \mathrm{R}$ & \\
\hline relative humidity & $\phi$ & 1.00 unitless & & & \\
\hline sat. pressure & $p_{w s}$ & 0.2370 psia & & & eqn (4) \\
\hline water vap. pres. & $\mathrm{p}_{\mathrm{w}}$ & 0.2370 psia & & & eqn (22) \\
\hline humidity ratio & $\mathrm{W}, \gamma$ & $0.010193 \mathrm{Ibm}_{\mathrm{w}} / \mathrm{lbm}_{\mathrm{a}}$ & 71.35 grains $/ \mathrm{bm}_{\mathrm{a}}$ & & eqn (20) \\
\hline sat. humidity ratio & $\mathrm{W}_{\mathrm{s}}$ & 0.010193 unitless & & & eqn (21) \\
\hline deg. of saturation & $\mu$ & 1.0000 unitless & & & eqn (10) \\
\hline specific volume & $v$ & $13.25 \mathrm{ft}^{3} / \mathrm{lbm}_{\mathrm{a}}$ & & & eqn (26) \\
\hline & & $13.11 \mathrm{ft}^{3} / \mathrm{lbm}$ & & & using $(1+\gamma)$ factor and eqn (26) \\
\hline & & $13.03 \mathrm{ft}^{3} / \mathrm{lbm}$ & & & using ideal gas law \\
\hline specific enthalpy & $\mathrm{h}$ & $24.87 \mathrm{BTU} / \mathrm{lbm}_{\mathrm{a}}$ & & & eqn (30) \\
\hline Differences & & & & & \\
\hline temperature & $\Delta \mathrm{t}$ & $-6.5 \mathrm{~F}$ & & & \\
\hline relative humidity & $\Delta \phi$ & 0.32 unitless & & & \\
\hline enthalpy & $\Delta \mathrm{h}$ & $0.00 \mathrm{BTU} / \mathrm{lbm}_{\mathrm{a}}$ & & & \\
\hline humidity ratio & $\Delta \mathrm{W}, \Delta \gamma$ & $0.001468 \mathrm{Ibm}_{\mathrm{w}} / \mathrm{lbm}_{\mathrm{a}}$ & 10.28 grains $/ \mathrm{bm}_{\mathrm{a}}$ & & \\
\hline Evaporation system & paramet & & & & \\
\hline Wind speed & $\mathrm{v}$ & $6.1 \mathrm{mi} / \mathrm{hr}$ & $8.95 \mathrm{ft} / \mathrm{s}$ & & \\
\hline Height & $\mathrm{h}$ & $20.0 \mathrm{ft}$ & & & \\
\hline Width & w & $100.0 \mathrm{ft}$ & & & \\
\hline Xsec area & $\mathrm{A}$ & $2000 \mathrm{ft}^{2}$ & & & \\
\hline $\begin{array}{r}\text { Incoming wet air } \\
\text { vol. flow }\end{array}$ & Q & $17893 \mathrm{ft}^{3} / \mathrm{s}$ & $1.1 \mathrm{E}+06 \mathrm{ft}^{3} / \mathrm{min}(\mathrm{cfm})$ & & \\
\hline Dry air mass flow & $\mathrm{m}_{\mathrm{a}}$ & $1337 \mathrm{lbm} / \mathrm{s}$ & & & \\
\hline Evaporation rate & $\mathrm{m}_{\mathrm{e}}$ & $1.96 \mathrm{lbm}_{\mathrm{w}} / \mathrm{s}$ & $117.77 \mathrm{lbm}_{\mathrm{w}} / \mathrm{min}$ & & \\
\hline Liq. water density & $\rho$ & $62.3 \mathrm{lbm} / \mathrm{ft}^{3}$ & & & @ 70F \\
\hline Evaporation rate & $\mathrm{Q}_{\mathrm{e}}$ & $0.032 \mathrm{ft}^{3} / \mathrm{s}$ & $14.1 \mathrm{gal} / \mathrm{min}$ & $848 \mathrm{~g}$ & \\
\hline
\end{tabular}


Solar evaporation: Evaporation from an open body of water exposed to atmospheric conditions is termed "solar evaporation" in this report. Evaporation rates from Class A land pans (unpainted galvanized metal, $4 \mathrm{ft}$ diameter, 10 in deep) have been measured by the U.S. Weather Bureau at 450 field locations across the United States (Fetter, 1988). Pan evaporation at the SRS is approximately $57 \mathrm{in} / \mathrm{yr}$ compared to average rainfall of 48$51 \mathrm{in} / \mathrm{yr}$ (Table 5). The evaporation rate from a large body of water (e.g. reservoir) is typically 70-80\% smaller than the pan evaporation rate on an annual average basis. Thus net evaporation rate from a large open pond at the SRS is estimated to be negligible (Table 7). This assessment agrees with experience with $\mathrm{H}$-area seepage basin \#3, which became plugged in the 1960's. Over a subsequent 3 year period, the water level in the basin was unchanged. Therefore, simple pond evaporation is not technically viable at the SRS.

Furthermore, an examination of the solar radiative properties listed in Table 8 suggests that only marginal improvement could be achieved by altering pond construction materials. Solar heating can be improved by increasing the absorptance of incoming short-wave solar radiation, and decreasing heat losses through emittance of thermal (longwave length) energy. Materials with high short-wave absorptance and low long-wave emittance are termed "selective" solar heating materials. Note that wet sand already has a high short-wave absorptance $(\alpha)$ compared to a perfect black-body $(\alpha=1)$. The longwave emittance $(\varepsilon)$ of wet sand is high, offering opportunity for improvement. However, no practical construction materials with low $\varepsilon$ were identified in this study. Galvanized sheet iron has relatively selective solar radiative properties, which should also be representative of a Class A land pan. In this respect, evaporation rates from a shallow pond lined with a selective solar material might be similar to pan evaporation rates. Even in this hypothetical and optimistic scenario, the net evaporation rate is marginal (Table 7, Upper limit). Thus solar evaporation is not technically viable at the SRS (Figure 2).

For future reference, it is noted that an efficiency for solar evaporation can be defined as the actual evaporation rate, e.g. Table 7, divided by the theoretical upper bound computed in Table 4. The efficiency of natural evaporation from an SRS pond is estimated to be roughly $40 \%$ (Figure 2, Table 9).

Table $7 \quad$ Upper limit, optimistic and pessimistic estimates of net pond evaporation at the Savannah River Site.

\begin{tabular}{|c|c|c|c|}
\hline \multicolumn{4}{|c|}{ Net natural evaporation } \\
\hline & limit & Optimistic & Pessimistic \\
\hline \begin{tabular}{|l|} 
Pan evaporation \\
\end{tabular} & $57 \mathrm{in} / \mathrm{yr}$ & $57 \mathrm{in} / \mathrm{yr}$ & $57 \mathrm{in} / \mathrm{yr}$ \\
\hline Pan coefficient & 1 & 0.8 & 0.7 \\
\hline Evaporation & $57 \mathrm{in} / \mathrm{yr}$ & $45.6 \mathrm{in} / \mathrm{yr}$ & $39.9 \mathrm{in} / \mathrm{yr}$ \\
\hline Rainfall & $48 \mathrm{in} / \mathrm{yr}$ & $48 \mathrm{in} / \mathrm{yr}$ & $51 \mathrm{in} / \mathrm{yr}$ \\
\hline Net & $9 \mathrm{in} / \mathrm{yr}$ & $-2.4 \mathrm{in} / \mathrm{yr}$ & $-11.1 \mathrm{in} / \mathrm{yr}$ \\
\hline & $0.46 \mathrm{gpm} / \mathrm{acre}$ & $-0.12 \mathrm{gpm} / \mathrm{acre}$ & $-0.57 \mathrm{gpm} / \mathrm{acre}$ \\
\hline
\end{tabular}


Table $8 \quad$ Selected solar radiative properties.

Radiative properties

\begin{tabular}{|rccccc|}
\hline & Water & Wet sand & $\begin{array}{c}\text { Bare moist } \\
\text { ground }\end{array}$ & $\begin{array}{c}\text { Rough } \\
\text { concrete }\end{array}$ & $\begin{array}{c}\text { Galvanized } \\
\text { sheet iron, } \\
\text { oxidized }\end{array}$ \\
\hline $\begin{array}{r}\text { Short-wave } \\
\text { absorptance }\end{array}$ & 0.94 & 0.91 & 0.90 & 0.60 & 0.80 \\
\hline $\begin{array}{r}\text { Long-wave } \\
\text { emittance }\end{array}$ & 0.955 & 0.95 & 0.95 & 0.97 & 0.28 \\
\hline
\end{tabular}

notes:

class A pan bottom probably has solar absorptance of 0.80 (black-body $=1.0$ )

earthen pond would have absorptance of about 0.90

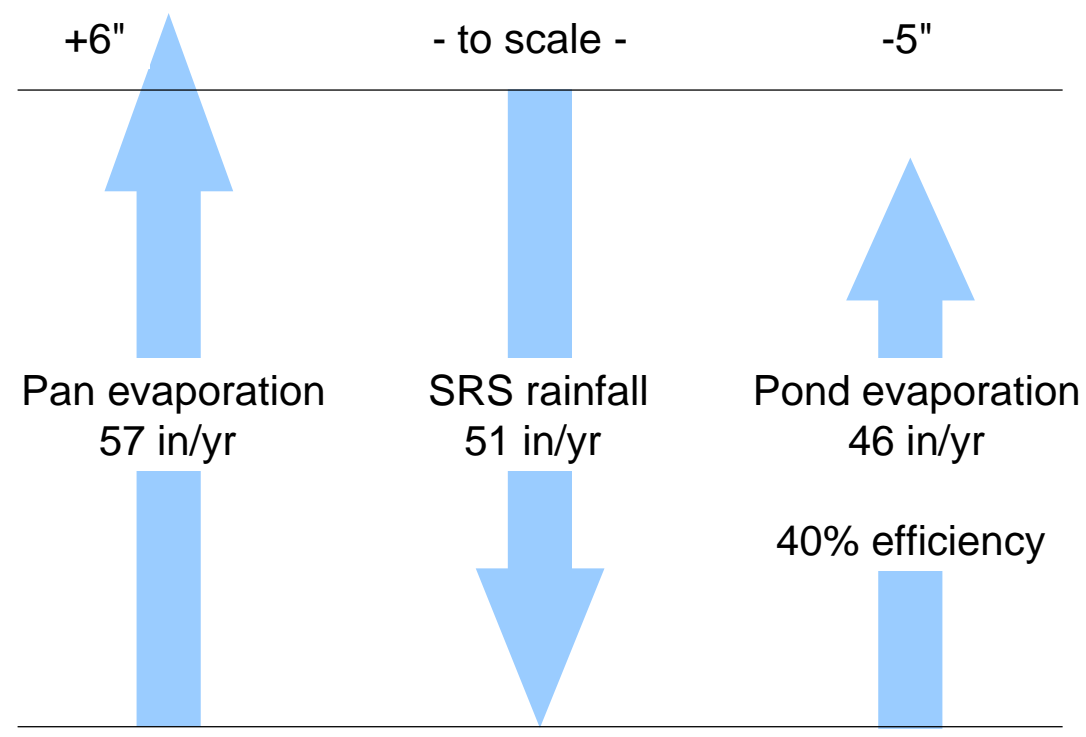

Figure 2 Graphical comparison of pan and pond evaporation to rainfall.

Table 9 Efficiency of solar evaporation.

Efficiency of natural evaporation

\begin{tabular}{|cccc|}
\hline \multicolumn{2}{|c|}{$\begin{array}{l}\text { Pan evaporation } \\
\text { (Solar surrogate?) }\end{array}$} & Optimistic lake evaporation & Nominal lake evaporation \\
\hline Insolation & $4.5 \mathrm{~kW}-\mathrm{hr} / \mathrm{m}^{2}-\mathrm{d}$ & $4.5 \mathrm{~kW}-\mathrm{hr} / \mathrm{m}^{2}-\mathrm{d}$ & $4.5 \mathrm{~kW}-\mathrm{hr} / \mathrm{m}^{2}-\mathrm{d}$ \\
\hline Production & $57 \mathrm{in} / \mathrm{yr}$ & $45.6 \mathrm{in} / \mathrm{yr}$ & $39.9 \mathrm{in} / \mathrm{yr}^{2}$ \\
\hline & $0.097 \mathrm{gal} / \mathrm{ft}^{2}-\mathrm{d}$ & $0.078 \mathrm{gal} / \mathrm{ft}^{2}-\mathrm{d}$ & $0.068 \mathrm{gal} / \mathrm{ft}^{2}-\mathrm{d}$ \\
\hline Upper bound & $0.18 \mathrm{gal} / \mathrm{ft}^{2}-\mathrm{d}$ & $0.18 \mathrm{gal} / \mathrm{ft}^{2}-\mathrm{d}$ & $0.18 \mathrm{gal} / \mathrm{ft}^{2}-\mathrm{d}$ \\
\hline Efficiency & $53 \%$ & $42 \%$ & $37 \%$ \\
\hline
\end{tabular}


Solar distillation: While significant evaporation occurs naturally from an open pond, rainfall essentially negates any net gain in water loss. Significant net gains in water evaporated can be achieved through solar distillation (Figure 3). The transparent cover eliminates any rainfall influx to the system, thus achieving a net gain even though the direct evaporation rate is smaller than an open evaporation system. Because the system is closed to the atmosphere, evaporation occurs solely through solar heating of the liquid pool. Water vapor subsequently condenses on the cooler underside of the transparent cover, and the clean distillate runs off to perimeter collection trays.

Solar stills are available commercially for home or personal use (e.g. Figure 3), but such models are too small and expensive to warrant further consideration. Large basin-type stills offer practical capacities and lower costs through economy of scale. Kreith and Kreider (1978, Figure 8.19) have collected production data for several large basin-type stills, and found that the average performance is well represented by the equation

$$
P=1.1 \times 10^{-3}\left(\frac{I_{s}}{100}\right)^{1.4}
$$

where $I_{s}$ is the solar insolation in BTU/ $\mathrm{ft}^{2}$-day and $P$ is the production of distillate in $\mathrm{gal} / \mathrm{ft}^{2}$-day. They note that the corresponding efficiency of large basin-type stills is about $25 \%$ at an insolation, which agrees with a Technical Brief published by The Schumacher Centre for Technology \& Development (http://www.itdg.org/). McCluney (1984) at the Florida Solar Energy Center reports production rates corresponding to efficiencies ranging from 25 to $40 \%$. The production rates under SRS conditions corresponding to these efficiency estimates are summarized in Table 10.

Solar distillation is technically viable, but at a typical evaporation rate of $1.37 \mathrm{gpm} / \mathrm{acre}$, clearly requires a large area to implement. The economic feasibility of solar distillation is considered later in the report. 


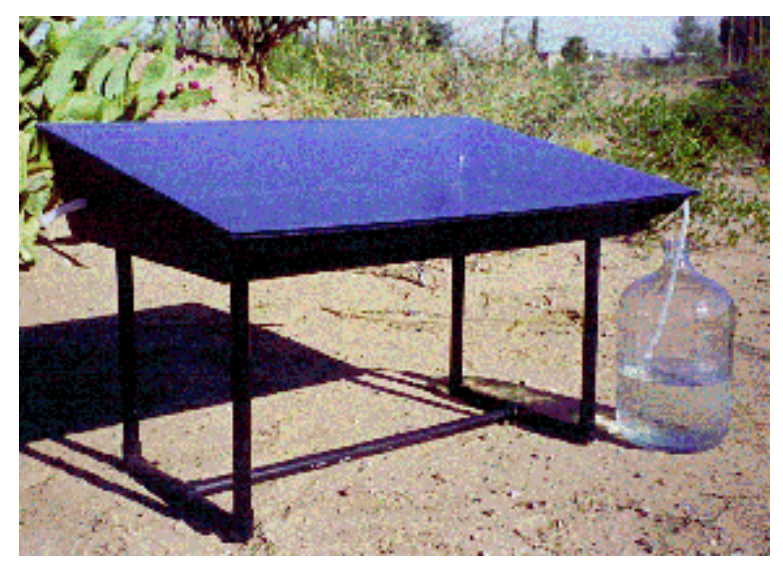

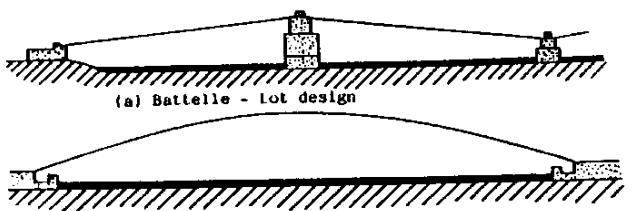

(b) Inflated plastic cover design

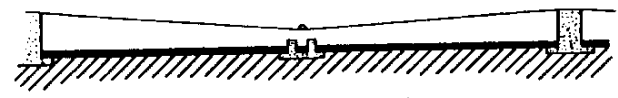

(c) V-ghape plastlc cover design

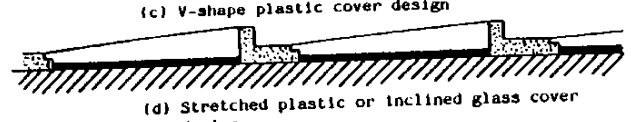

(d) Stretched plastic or inclined blass cover
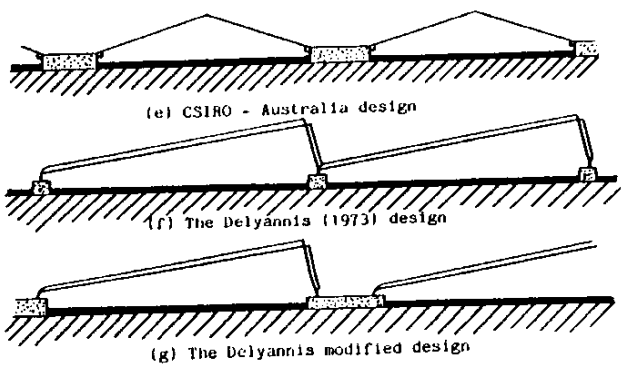

Figure 3 Examples of small and large-scale solar distillation designs.

Table 10 Production and efficiency of solar distillation under SRS conditions.

Estimated distillation rates under SC conditions - large basin stills

\begin{tabular}{|c|c|c|c|}
\hline & Kreith \& Kreider (1978) & FSEC-EN-3 (1984) & Schumacher Centre for \\
\hline \multirow[t]{2}{*}{ Insolation } & $4.5 \mathrm{~kW}-\mathrm{hr} / \mathrm{m}^{2}-\mathrm{d}$ & $4.5 \mathrm{~kW}-\mathrm{hr} / \mathrm{m}^{2}-\mathrm{d}$ & Technology \& Development \\
\hline & $1427 \mathrm{BTU} / \mathrm{d}-\mathrm{ft}^{2}$ & & \\
\hline \multirow[t]{4}{*}{ Production } & $0.045 \mathrm{gal} / \mathrm{ft}^{2}-\mathrm{d}$ & $0.059 \mathrm{gal} / \mathrm{ft}^{2}-\mathrm{d}$ & $0.046 \mathrm{gal} / \mathrm{ft} 2-\mathrm{d}$ \\
\hline & $0.49 \mathrm{gal} / \mathrm{m}^{2}-\mathrm{d}$ & $0.64 \mathrm{gal} / \mathrm{m}^{2}-\mathrm{d}$ & $0.49 \mathrm{gal} / \mathrm{m}^{2}-\mathrm{d}$ \\
\hline & $26.6 \mathrm{in} / \mathrm{yr}$ & $34.8 \mathrm{in} / \mathrm{yr}$ & $26.9 \mathrm{in} / \mathrm{yr}$ \\
\hline & $1.37 \mathrm{gpm} / \mathrm{acre}$ & $1.80 \mathrm{gpm} / \mathrm{acre}$ & $1.39 \mathrm{gpm} / \mathrm{acre}$ \\
\hline Upper bound & $0.18 \mathrm{gal} / \mathrm{ft}^{2}-\mathrm{d}$ & $0.18 \mathrm{gal} / \mathrm{ft} 2-\mathrm{d}$ & $0.18 \mathrm{gal} / \mathrm{ft} 2-\mathrm{d}$ \\
\hline Efficiency & $25 \%$ & $32 \%$ & $25 \%$ \\
\hline
\end{tabular}

BASIC ELENENTS IN ASOLAR STIL 1) Inooring Fadation [Energy) 1) Condersation of Wister Vapor (Condensati) The inside of to basin is usuaty back to stmilenfy absarb radistion and insultod on fie buttom to rotaln hsat.

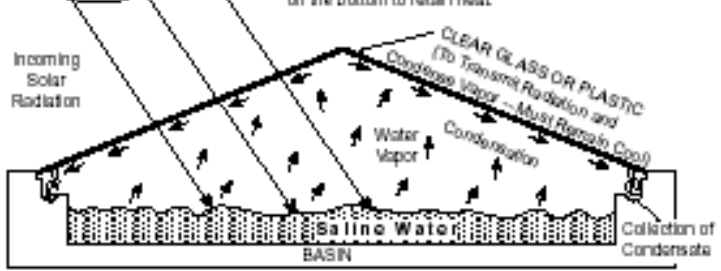
2] Water Wapor Ptodust on torm Balna Wassr 
Spray evaporation: In contrast to solar evaporation and distillation, spray evaporation relies on the sensible heat that can be extracted from low $(<100 \%)$ humidity air to drive evaporation. Incoming dry air is brought into contact with a fine droplet spray, and simultaneously cooled and humidified through evaporative cooling. The evaporation rate is controlled by a number of factors. Important factors are the flowrate, temperature, and humidity of the incoming air stream, and the distribution, residence time, and size of spray droplets. As hot, dry, windy conditions are most favorable to spray evaporation, field applications are primarily in arid or semi-arid portions of the United States. Quantitative performance or design data for the Southeast US was essentially unavailable from the those vendors supplying industrial sprayers for wastewater evaporation identified in an internet search.

Snow Machines, Inc. (SMI) manufactures sprayers designed for industrial wastewater evaporation using modified snow-making technology. A sales representative reported that a client in NE South Dakota evaporated 300 acre-ft of water from a 300 acre holding pond over a 7 month (summer?) period using 20 SMI sprayers. The climate at the site is uncertain, but the analysis shown in Table 11 produces net evaporation (rainfall - solar evaporation) estimates of 3.6 and $5 \mathrm{in} / \mathrm{yr}$. So, not all of the $300 \mathrm{acre-ft}$ water loss can be attributed to the use of sprayers. The net effect of spray evaporation is estimated to be 12 to $16 \mathrm{gpm}$ per machine (Table 12). Relative to the supply flowrate of approximately 77.5 gpm, the efficiency ranged from 16 to $21 \%$.

The annual average temperature and humidity for NE South Dakota are estimated to be $46^{\circ} \mathrm{F}$ and $26 \%$ (Table 11), compared to $64^{\circ} \mathrm{F}$ and $68 \%$ at the SRS (Table 5). To estimate the performance of spray evaporation at the SRS based on field experience in South Dakota, the adiabatic saturation /swamp cooler calculation in Table 6 is repeated in Table 13 for South Dakota temperature and humidity. The estimated evaporation rate for South Dakota temperature and humidity conditions is $25.5 \mathrm{gpm}$, compared to $14.1 \mathrm{gpm}$ under SRS conditions. That is, adiabatic saturation rate for the SRS is 55\% of the rate for South Dakota. This suggests that SMI sprayer performance at the SRS might be on the order of $7 \mathrm{gpm}$ per sprayer and $9 \%$ efficiency.

The evaporation rate that could be achieved through spraying would exhibit daily and seasonal fluctuations, due to daily and seasonal temperature and humidity variations. The lowest evaporation rates at the SRS would probably occur in January, when the average temperature is about $46^{\circ} \mathrm{F}$. Monthly average humidity is about the same as the annual average of $68 \%$. An adiabatic saturation calculation for January conditions is shown in Table 14. The estimated evaporation rate of $10.5 \mathrm{gpm}$ is $74 \%$ of the annual average result of $14.1 \mathrm{gpm}$ in Table 6.

In addition to evaporation rate, spray drift is another important technical consideration. Because most of the contaminated feed water falls to the ground, spray evaporation would presumably have to be combined with a lined catch basin of sufficient size to avoid significant spray drift problems. Snow Machines, Inc. reports that clients typically shut down spray evaporators if the wind speed exceeds approximately $10 \mathrm{mph}$. Apart from that statement, technical data on spray drift was not available from vendors through either 
published information or personal contacts with sales representatives. Field experiments at the SRS using rental units are suggested as the best approach for quantifying spray drift under SRS conditions.
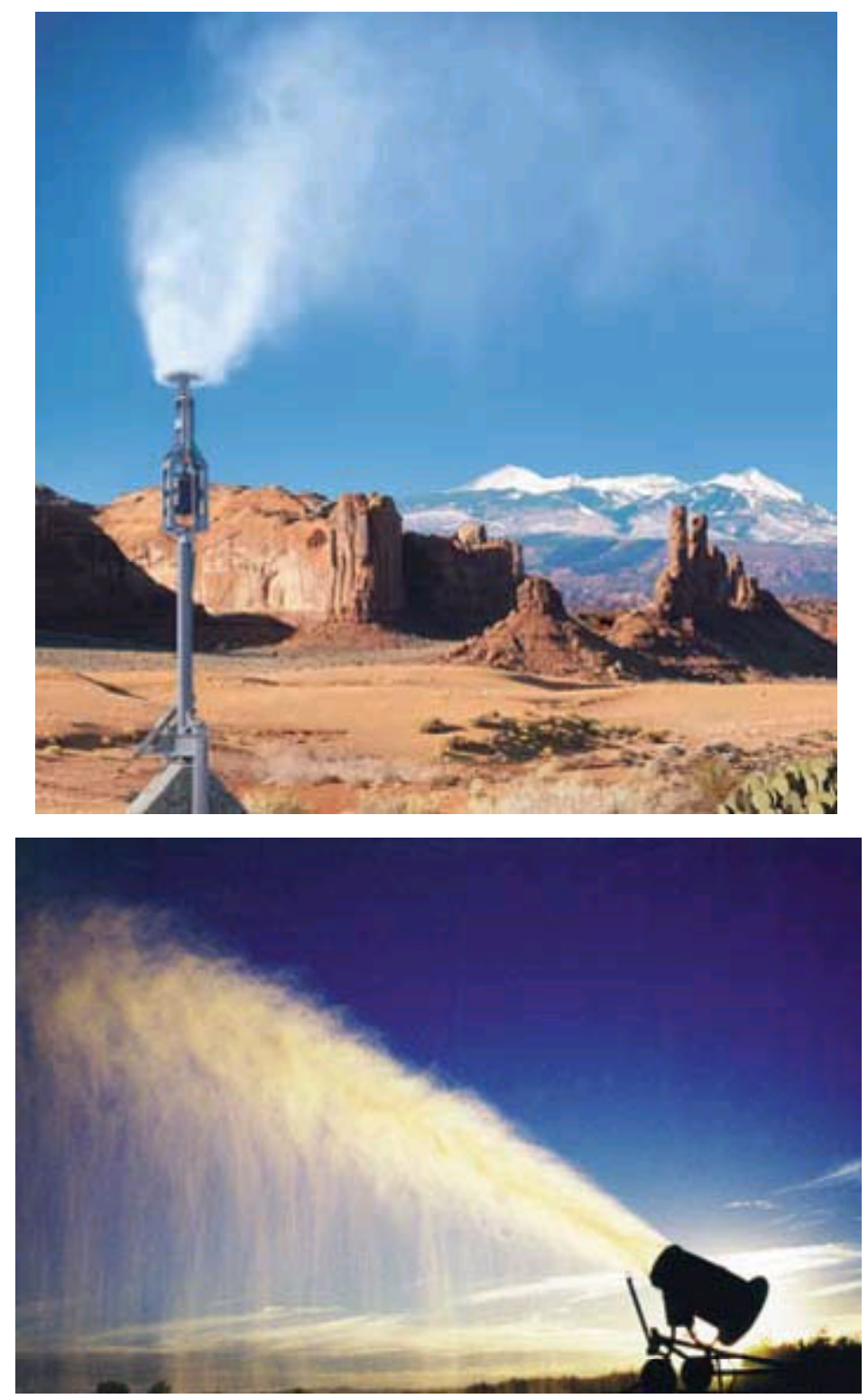

Figure 4 Spray evaporation using snow-making technology modified for wastewater treatment (photos reproduced from Snow Machines Inc. website). 
Table 11 Estimated climate at location of Snow Machines Inc. client in NE South Dakota.

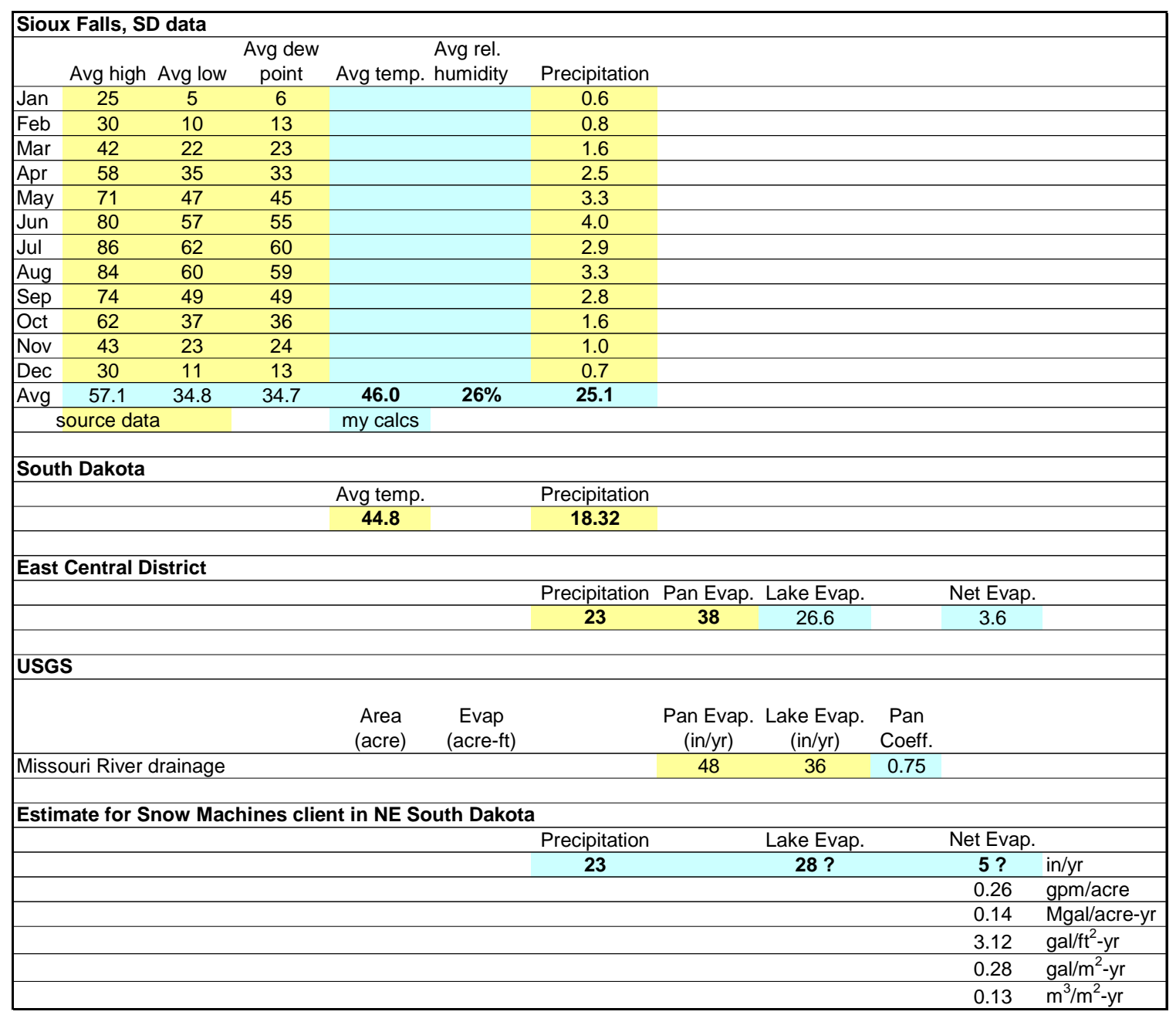


Table 12 Analysis of Snow Machines Inc. application in NE South Dakota.

\begin{tabular}{|c|c|c|c|}
\hline \multicolumn{3}{|c|}{ Snow Machines client in NE South Dakota } & \multirow[t]{2}{*}{ (summer use?) } \\
\hline Total losses & & & \\
\hline loss & 300 acre-ft & & \\
\hline time & 7 months & & \\
\hline rate & $319 \mathrm{gal} / \mathrm{min}$ & 514 acre-ft/yr & \\
\hline area & 300 acre & & \\
\hline flux & $20.6 \mathrm{in} / \mathrm{yr}$ & & \\
\hline machines & 20 & & \\
\hline \multicolumn{4}{|c|}{ Net lake evaporation } \\
\hline flux & $0 ? \mathrm{in} / \mathrm{yr}$ & $3.6 ? \mathrm{in} / \mathrm{yr}$ & $5 ? \mathrm{in} / \mathrm{yr}$ \\
\hline \multicolumn{4}{|c|}{ Snow machine net effect (marginal increase) } \\
\hline flux & $20.6 \mathrm{in} / \mathrm{yr}$ & $17.0 \mathrm{in} / \mathrm{yr}$ & $15.6 \mathrm{in} / \mathrm{yr}$ \\
\hline rate & $319 \mathrm{gal} / \mathrm{min}$ & $263 \mathrm{gal} / \mathrm{min}$ & $241 \mathrm{gal} / \mathrm{min}$ \\
\hline rate/machine & $15.9 \mathrm{gal} / \mathrm{min}$ & $13.2 \mathrm{gal} / \mathrm{min}$ & $12.1 \mathrm{gal} / \mathrm{min}$ \\
\hline supply flow & $77.5 \mathrm{gal} / \mathrm{min}$ & $77.5 \mathrm{gal} / \mathrm{min}$ & $77.5 \mathrm{gal} / \mathrm{min}$ \\
\hline efficiency & $21 \%$ & $17 \%$ & $16 \%$ \\
\hline
\end{tabular}


Table 13 Adiabatic saturation calculation for South Dakota conditions, a $6.1 \mathrm{mph}$ wind, and a $20 \mathrm{ft}$ by $100 \mathrm{ft}$ cross-sectional area.

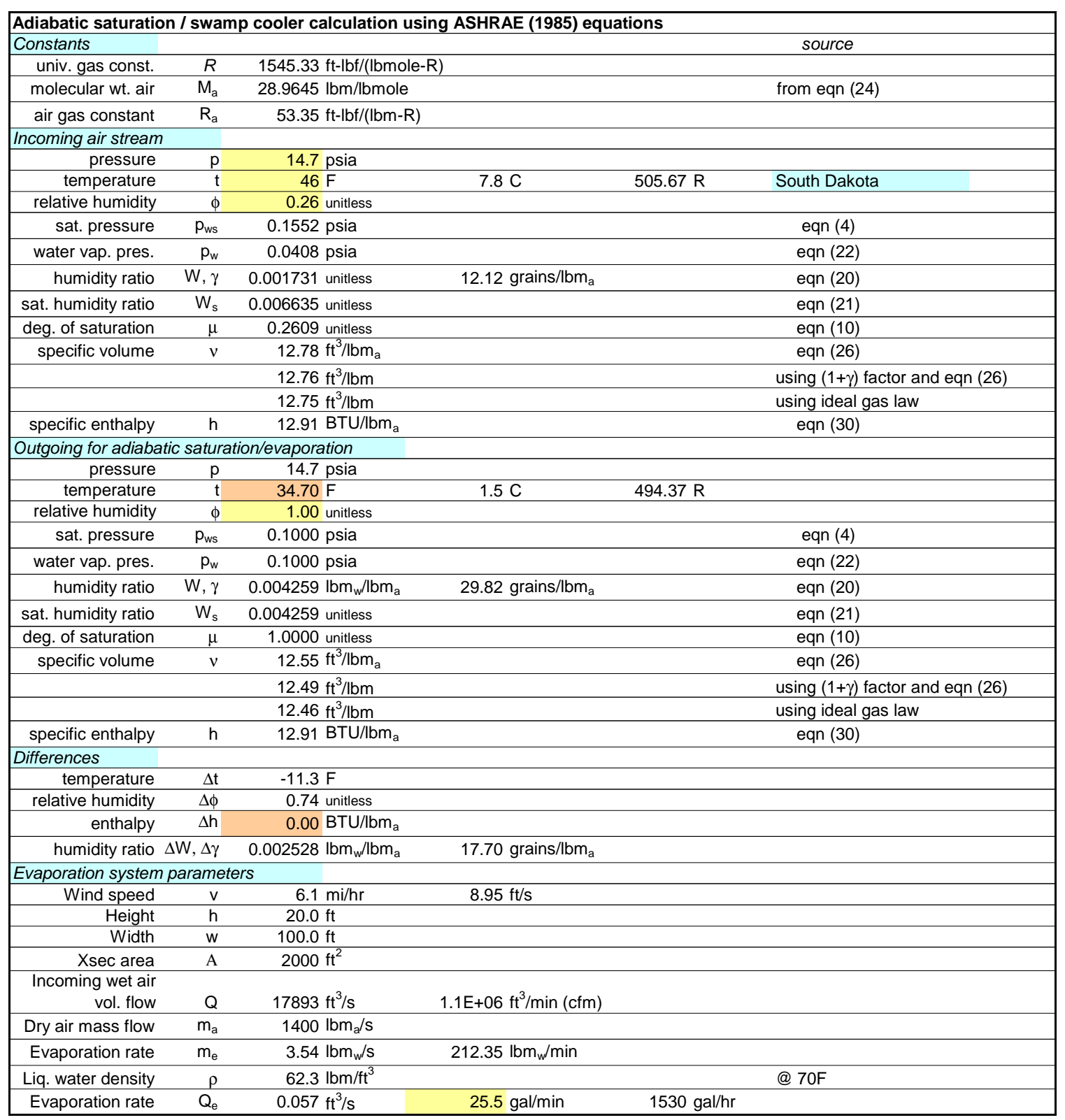


Table 14 Adiabatic saturation calculation for average SRS conditions in January and a $20 \mathrm{ft}$ by $100 \mathrm{ft}$ cross-sectional area.

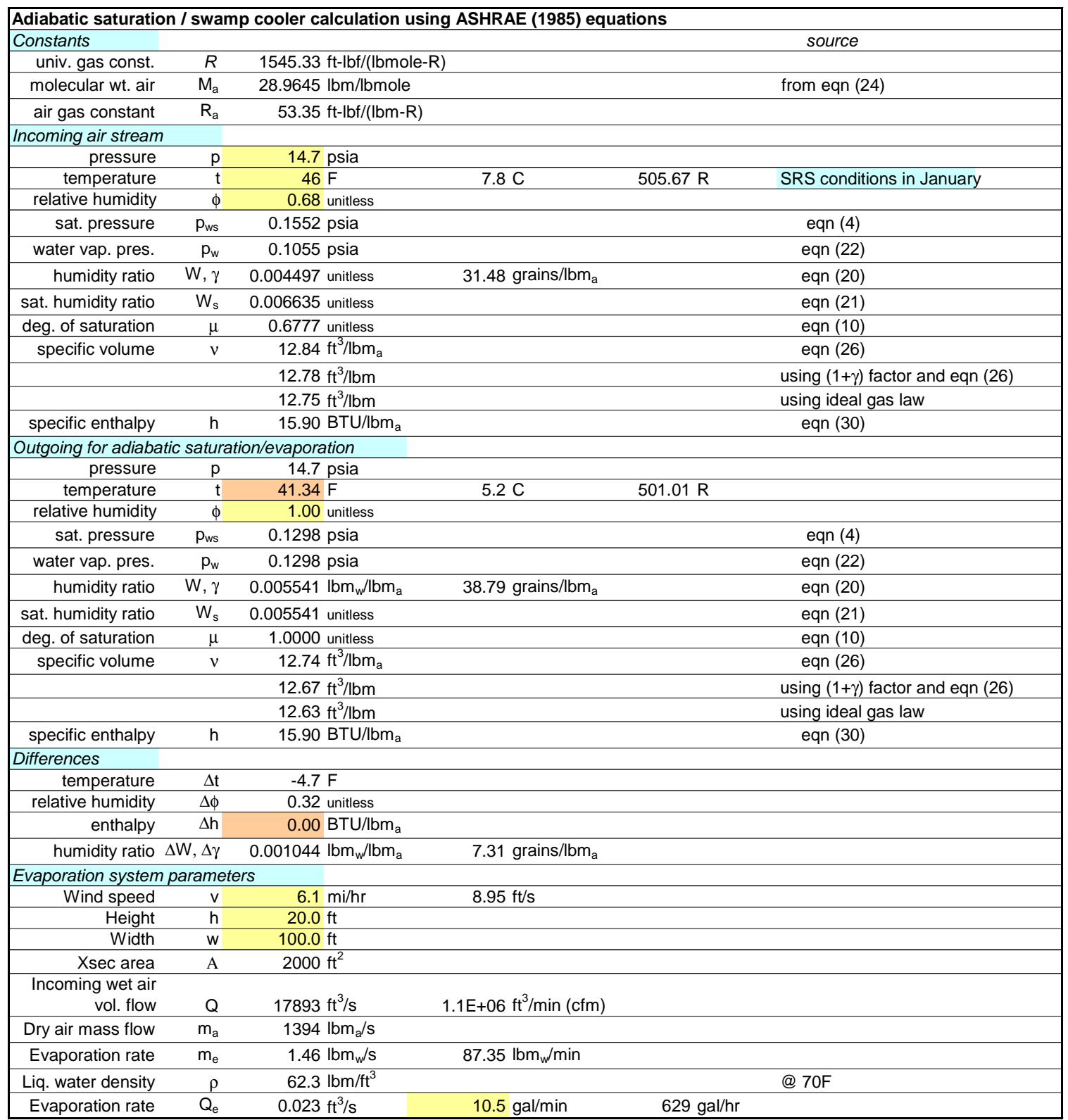


Combined solar and spray evaporation: At a conceptual level, passive evaporation can be optimized through the following enhancements to the technologies considered above:

1. utilize both forms of passive energy, solar insolation and "dry" air sensible heat

2. maximize solar heating

3. maximize contact with wind-driven ambient air

4. eliminate rainfall influx

A conceptual design with the above attributes is depicted in Figure 5. Item 1. is achieved by utilizing both solar and spray evaporation during normal operation. Solar heating is maximized by using a black-body liner floating on the water surface. Solar insolation goes primarily toward heating a thin film of water on the upper surface of the liner, resulting from collection of un-evaporated spray droplets. Contact with ambient air is maximized through the use of commercial sprayers with a large throw (e.g. Figure 4). Rainfall is eliminated from the system by inflating the surface liner with air during rain events (Figure 5). Air inflation would be accomplished through a small blower discharging beneath the cover. The technology of air inflated structures is well established and used in a variety of applications (e.g. stadiums, agricultural crop drying, temporary buildings).

In principle, such a system might evaporate $50 \mathrm{gpm}$ on an annual average basis, using a 10 acre lined catch basin and 3 SMI sprayers (Table 15). However, this performance estimate is highly uncertain. The spray evaporation rate is uncertain because rigorous technical performance data from vendors is not available for SRS conditions. The pond evaporation rate using the shallow liner is assumed to be the same as pan evaporation for this climate, but the actual rate is unknown. Also, spray evaporation over the pond would reduce pond evaporation, so the individual spray and pond evaporation rates are not directly additive in practice. Spray evaporation would cool and humidify the ambient air, and un-evaporated droplets falling to the pond would cool the surface water. So, while the concept looks rather promising, technical feasibility must be graded low given the approach is only at a conceptual stage. 


\section{Normal operation}

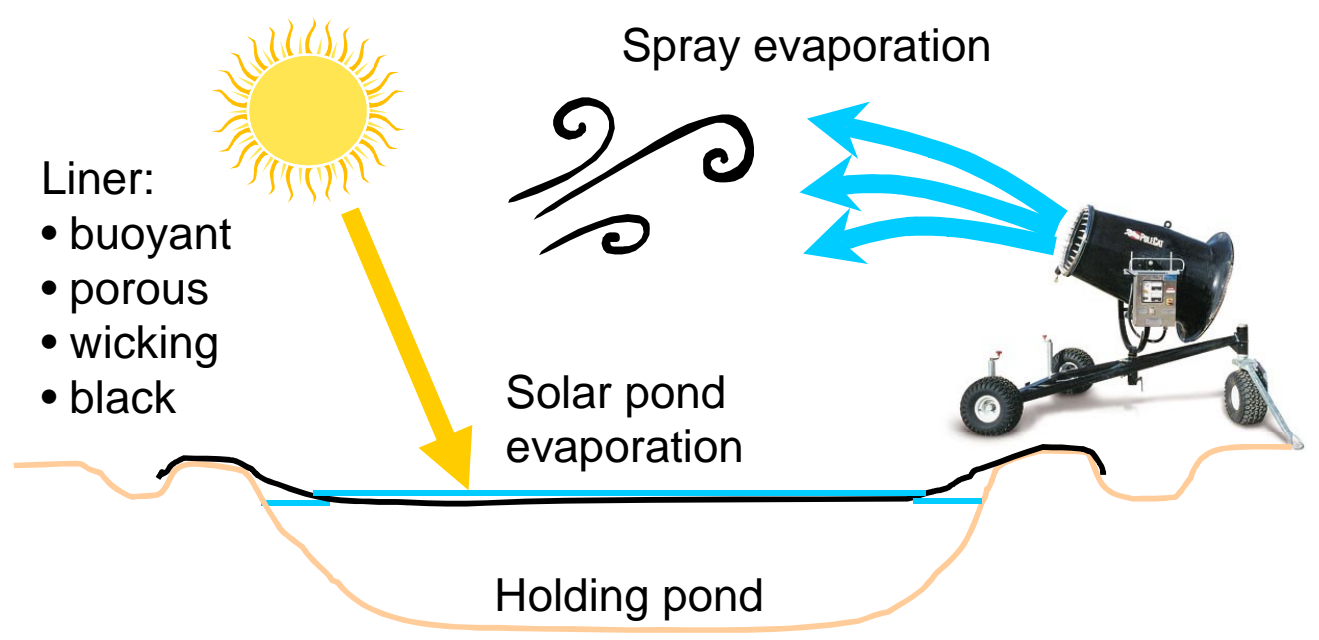

\section{Rainfall operation}

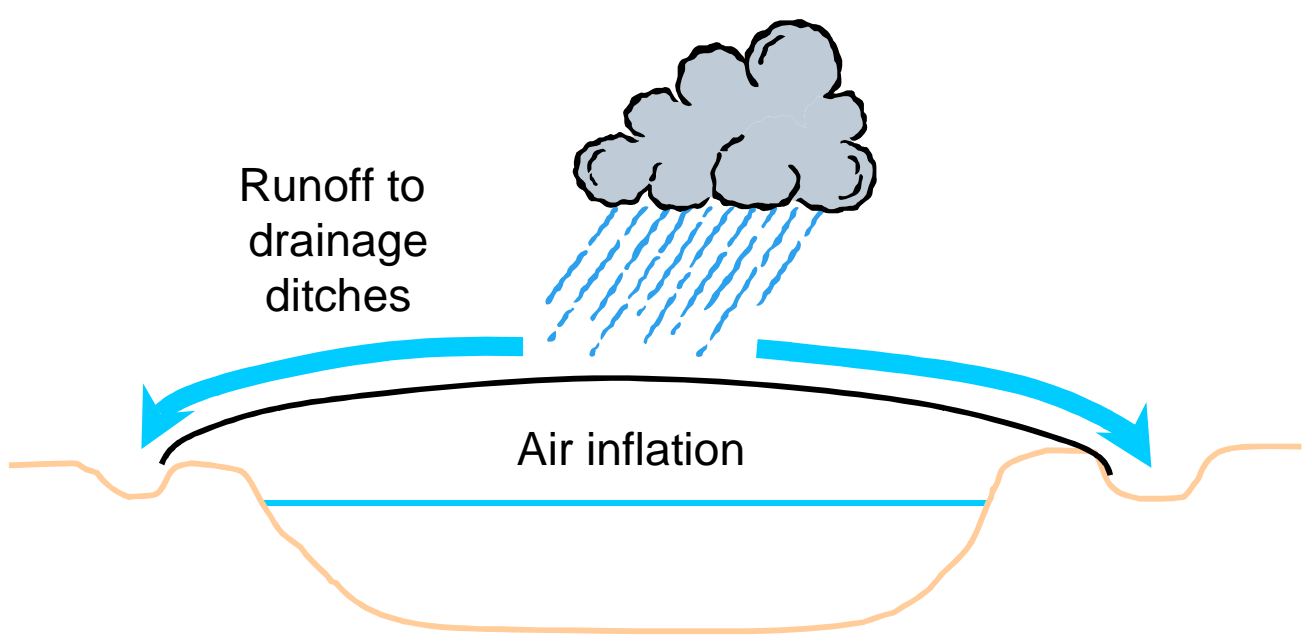

Figure 5 Conceptual design of an optimal passive evaporation system. 
Table 15 Estimated performance of an optimal conceptual design for passive evaporation of contaminated groundwater.

\begin{tabular}{|cc|}
\hline Design specs. \\
\hline Flowrate needed & $50 \mathrm{gpm}$ \\
\hline Conceptual design & \\
\hline Spray evaporation & $7.25 \mathrm{gpm} /$ machine \\
\hline & $3 \mathrm{machines}$ \\
\hline & $21.75 \mathrm{gpm}$ \\
\hline +Solar evaporation & $28.25 \mathrm{gpm}$ \\
\hline & $57 \mathrm{in} / \mathrm{yr} \quad$ pan evaporation rate \\
\hline & $2.94 \mathrm{gpm} /$ acre \\
\hline & $9.6 \mathrm{acres}$ \\
\hline
\end{tabular}

\section{Active evaporation technologies for liquid concentration}

In the context of this report, "active" refers to an engineered source of energy such as fossil fuel or nuclear power. As discussed earlier, evaporation by simple direct heating is expensive for a purchased energy source (Table 1). Energy efficiency can be significantly increased through the use of multiple-effects, and heat pump technologies such as Mechanical Vapor Recompression.

Multiple effects refers to multiple boiling-condensation cycles operated in combination, where vapor from the first effect becomes the heat source for the second effort, and so forth. Each subsequent effect is operated at a higher vacuum than the previous effect. Many evaporators are steam driven. A single-effect steam-driven evaporator is said to have a theoretical "economy" of 1 , in that $1 \mathrm{lbm}$ of steam supplied can theoretically evaporate $1 \mathrm{lbm}$ of feed water. The actual economy is lower due to preheating requirements, heat losses, and other factors. A two-effect evaporator has an economy of roughly 2 . In other words, only $1 / 2 \mathrm{lbm}$ of steam is needed to evaporate $1 \mathrm{lbm}$ of feed water. In general, an $n$-effect evaporator has a nominal/theoretical economy of $n$. Capital equipment costs increase with each added effect, and counter-balance energy savings. The lowest total cost (capital + operating) is usually achieved with a small number of multiple-effects.

Mechanical Vapor Recompression (MVR) also offers significant energy savings compared to single-effect direct heating evaporation. With MVR added to a single-effect evaporator operating under vacuum, vapor from the separator is mechanically compressed to the pressure corresponding to the saturation temperature required on the steam side of the heat exchanger. Essentially, the energy required to produce the vapor is recovered by recompression and used to vaporize additional feed water. Typically, little or no steam input is required to an MVR system after start-up. Most of the energy cost comes from the electricity required to drive the compressor motor. 
Scale buildup on heat exchanger surfaces can be a serious problem with evaporation technology in general, and leads to lower energy efficiency and capacity. Scaling is not expected to be a significant issue for $\mathrm{F}$ - and $\mathrm{H}$-area groundwater treatment. For a concentration factor on the order of 100:1, precipitation of dissolved solids should be minimal.

Compared to passive/solar evaporation, active evaporation technologies are well developed and readily available from commercial vendors. Technical feasibility is not an issue.

\section{Technologies for reduction to dry solids}

Evaporation can also be used to reduce a concentrated solute to a dry solid. Such an operation is typically referred to as a "drying" or "crystallization". Again, active technologies are well developed and commercially available, so technical feasibility is not an issue. One technology of interest is spray drying involving flash evaporation (Figure 6). Feed wastewater is sprayed into a high-temperature combustion chamber as atomized droplets. Water is instantly vaporized, and metals and non-volatile radionuclides collect in the bottom of the combustion chamber or exhaust filter as a dry ash residue. Any combustible solutes are incinerated. Assuming groundwater is first concentrated by say 100:1 in a prior process, the flowrate going to the flash evaporator would be very small. Energy and capital equipment costs are then relatively low. Air permitting may be an issue with this technology. 


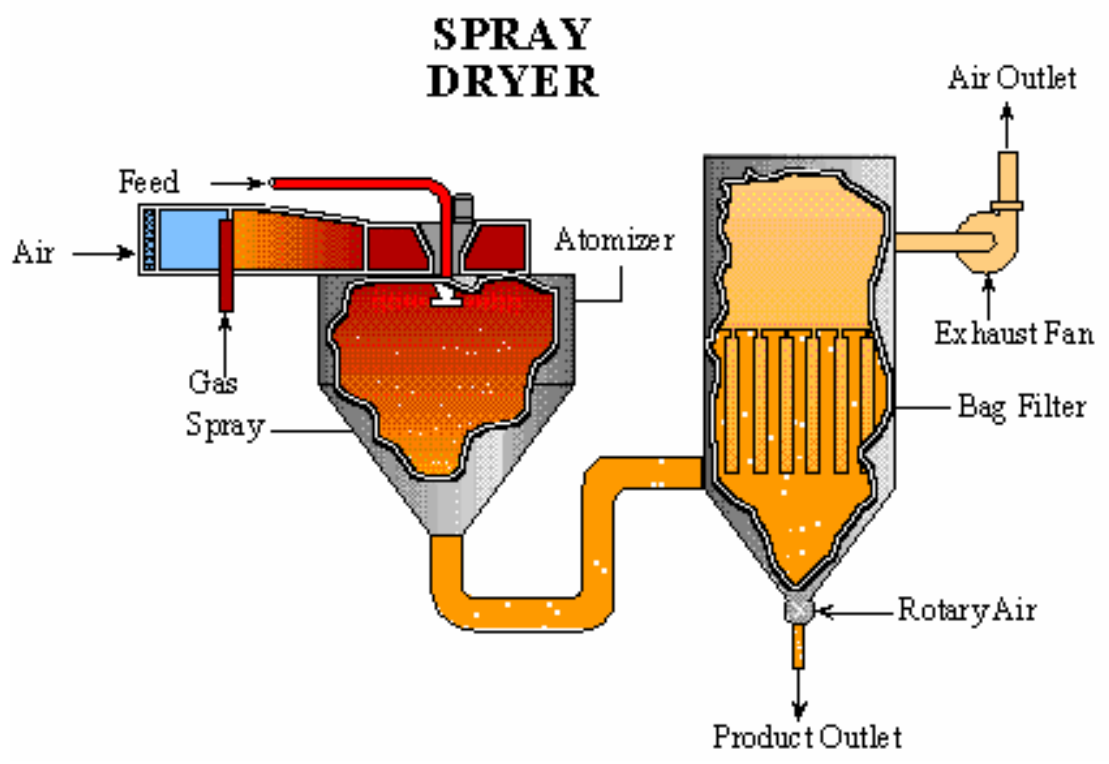

Figure 6 Example spray dryer (reproduced from www.ionics.com).

\section{Economic analysis}

Active evaporation technologies are well developed and robust, and some passive evaporation designs also appear to be technically feasible. For these technologies, cost is a primary consideration in assessing alternatives to the F- and $\mathrm{H}$-area WTUs. Because the Water Treatment Units have already been built, capital cost for continued operation of the current systems is essentially zero, and only operating costs are relevant to a cost comparison. For any alternative, both capital and operating costs must be considered. This immediately puts evaporation technologies at a financial disadvantage, as capital costs are significant for these alternatives.

In any analysis involving future income or expenses, the "time value of money" should be recognized. Amounts occurring in the future are inherently less valuable, and should therefore be discounted according an appropriate discount or interest rate. US Office of Management and Budget Circular No. A-94 provides guidance on selecting a discount rate. In this study, the life span of capital equipment is assumed to be 20 years, and the discount rate is set to the interpolated real (inflation adjusted) Treasury rate for a 20 year term, averaged over the past 20 years. As shown in Table 16, this rate is $4.4 \%$.

With any alternative, the total cost will be comprised of an initial capital cost and ongoing operating costs over the life of the facility. The time value of money concept can be used to convert a uniform monetary amount (A) occurring each interest period into an equivalent present value $(\mathrm{P})$, for direct comparison to present capital costs. Conversely, a present value $(\mathrm{P})$ can be translated into an equivalent series of uniform amounts paid each 
interest period (A). The formulas for these "uniform series present worth" and "capital recovery" conversions are given in Table 17. For an annual interest rate of $4.4 \%$ and 20 years, the capital recovery factor is 0.0762 . In the analyses that follow, capital costs are converted into annualized capital costs using a capital recovery factor. Annualized capital costs plus annual operating costs constitute the annual total cost of an alternative. For convenience, this amount is divided by the annual volume of groundwater treated, yielding total cost per gallon treated (i.e. \$/gal).

To convert historical amounts into 2001 constant dollars for example, the Consumer Price Index generated by the US Bureau of Labor Statistics (Table 18) is used as follows

$$
2001 \$=\frac{2001 C P I}{y C P I} \times y \$
$$

where $y$ is the historical year. Equation (2) is an adjustment for inflation. Occasionally costs in the literature are cited in a foreign currency. In this study, such amounts are converted to US \$ using current exchange rates.

Table 16 Forecast real US Treasury interest rates over the past 20 years.

\begin{tabular}{|cccc|}
\hline $\begin{array}{c}\text { Forecast } \\
\text { Date }\end{array}$ & $\mathbf{1 0} \mathbf{~ y r}$ & $\mathbf{3 0} \mathbf{~ y r}$ & $\mathbf{2 0} \mathbf{~ y r}$ interpolated \\
\hline 1983 & 5.3 & 5.6 & 5.5 \\
\hline 1984 & 6.1 & 6.4 & 6.3 \\
\hline 1985 & 7.1 & 7.4 & 7.3 \\
\hline 1986 & 5.9 & 6.7 & 6.3 \\
\hline 1987 & 3.8 & 4.4 & 4.1 \\
\hline 1988 & 5.1 & 5.6 & 5.4 \\
\hline 1989 & 5.8 & 6.1 & 6.0 \\
\hline 1990 & 4.2 & 4.6 & 4.4 \\
\hline 1991 & 3.9 & 4.2 & 4.1 \\
\hline 1992 & 3.6 & 3.8 & 3.7 \\
\hline 1993 & 4.3 & 4.5 & 4.4 \\
\hline 1994 & 2.7 & 2.8 & 2.8 \\
\hline 1995 & 4.8 & 4.9 & 4.9 \\
\hline 1996 & 2.8 & 3.0 & 2.9 \\
\hline 1997 & 3.5 & 3.6 & 3.6 \\
\hline 1998 & 3.6 & 3.8 & 3.7 \\
\hline 1999 & 2.7 & 2.9 & 2.8 \\
\hline 2000 & 4.0 & 4.2 & 4.1 \\
\hline 2001 & 3.2 & 3.2 & 3.2 \\
\hline 2002 & 3.1 & 3.9 & 3.5 \\
\hline 20 yr average & & 4.4 \\
\hline
\end{tabular}


Table 17 Time value of money financial formulas.

\begin{tabular}{|l|l|}
\hline Factor & Formula \\
\hline Capital recovery & A/ $P=\frac{i(1+i)^{n}}{(1+i)^{n}-1}$ \\
\hline Uniform series present worth & $P / A=\frac{(1+i)^{n}-1}{i(1+i)^{n}}$ \\
\hline
\end{tabular}

Table $18 \quad$ Consumer Price Indices for 1970 through 2001.

\begin{tabular}{|cc|}
\hline year & CPI \\
\hline 1970 & 38.8 \\
1971 & 40.5 \\
1972 & 41.8 \\
1973 & 44.4 \\
1974 & 49.3 \\
1975 & 53.8 \\
1976 & 56.9 \\
1977 & 60.6 \\
1978 & 65.2 \\
1979 & 72.6 \\
1980 & 82.4 \\
1981 & 90.9 \\
1982 & 96.5 \\
1983 & 99.6 \\
1984 & 103.9 \\
1985 & 107.6 \\
1986 & 109.6 \\
1987 & 113.6 \\
1988 & 118.3 \\
1989 & 124.0 \\
1990 & 130.7 \\
1991 & 136.2 \\
1992 & 140.3 \\
1993 & 144.5 \\
1994 & 148.2 \\
1995 & 152.4 \\
1996 & 156.9 \\
1997 & 160.5 \\
1998 & 163.0 \\
1999 & 166.6 \\
2000 & 172.2 \\
2001 & 177.1 \\
\hline & \\
\hline
\end{tabular}




\section{Passive technologies}

Solar evaporation, solar distillation, spray evaporation, and optimal solar and spray evaporation were analyzed above for technical viability. Solar evaporation, and spray evaporation without a collection pond, were determined to be technically unfeasible. Solar distillation is clearly feasible from a technical standpoint. The conceptual design for an optimal combined solar and spray evaporation system shown in Figure 5 is unproven, but appears very promising from a cost perspective. These latter two technologies warrant further financial analysis.

Cost data from the 1970's and 1980's for solar distillation is available from the sources listed in Table 10. The cost of solar distillation is almost entirely comprised of capital costs. As shown in Table 19, the solar distillation is estimated to cost approximate $\$ 0.03$ per gallon evaporated. Labor costs for operating the still are not included, but should be minimal. Solar distillation appears to be competitive with current operating costs of the F- and H-area WTUs (0.047 \$/gal, Table 2) in a best-estimate sense.

For the combined solar and spray evaporation system shown in Figure 5, cost analysis is more difficult because the design is only at the conceptual stage. Nevertheless, a scoping analysis of costs can be developed using vendor and commercial pricing as shown in Table 20. Design costs and labor for system operation are not considered. The result, $\$ 0.005 /$ gal, is rather encouraging, but highly uncertain and incomplete.

Table 19 Cost analysis for large basin-type solar distillation under SC conditions.

\begin{tabular}{|c|c|c|c|}
\hline & Kreith \& Kreider (1978) & FSEC-EN-3 (1984) & Schumacher Centre for \\
\hline \multirow[t]{2}{*}{ Insolation } & $4.5 \mathrm{~kW}-\mathrm{hr} / \mathrm{m}^{2}-\mathrm{d}$ & $4.5 \mathrm{~kW}-\mathrm{hr} / \mathrm{m}^{2}-\mathrm{d}$ & Technology \& Development \\
\hline & $1427 \mathrm{BTU} / \mathrm{d}-\mathrm{ft}^{2}$ & & \\
\hline \multirow[t]{4}{*}{ Production } & $0.045 \mathrm{gal} / \mathrm{ft}^{2}-\mathrm{d}$ & $0.059 \mathrm{gal} / \mathrm{ft}^{2}-\mathrm{d}$ & $0.046 \mathrm{gal} / \mathrm{ft} 2-\mathrm{d}$ \\
\hline & $0.49 \mathrm{gal} / \mathrm{m}^{2}-\mathrm{d}$ & $0.64 \mathrm{gal} / \mathrm{m}^{2}-\mathrm{d}$ & $0.49 \mathrm{gal} / \mathrm{m}^{2}-\mathrm{d}$ \\
\hline & $26.6 \mathrm{in} / \mathrm{yr}$ & $34.8 \mathrm{in} / \mathrm{yr}$ & $26.9 \mathrm{in} / \mathrm{yr}$ \\
\hline & $1.37 \mathrm{gpm} / \mathrm{acre}$ & $1.80 \mathrm{gpm} / \mathrm{acre}$ & $1.39 \mathrm{gpm} / \mathrm{acre}$ \\
\hline Upper bound & $0.18 \mathrm{gal} / \mathrm{ft}^{2}-\mathrm{d}$ & $0.18 \mathrm{gal} / \mathrm{ft} 2-\mathrm{d}$ & $0.18 \mathrm{gal} / \mathrm{ft} 2-\mathrm{d}$ \\
\hline Efficiency & $25 \%$ & $32 \%$ & $25 \%$ \\
\hline Capital costs & $2.25 \sim 1975$ US $\$ / \mathrm{ft}^{2}$ & $50 \sim 1984$ US $\$ / m^{2}$ & $60 \mathrm{UK} \$ / \mathrm{m}^{2}$ \\
\hline Currency factor & 1 & 1 & 1.46 \\
\hline Inflation factor & 3.29 & 1.70 & $1 ?$ \\
\hline \multirow[t]{2}{*}{2001 US\$ } & $7.4 \mathrm{US} \$ / \mathrm{ft}^{2}$ & $7.9 \mathrm{US} \$ / \mathrm{ft}^{2}$ & $8.1 \mathrm{US} \$ / \mathrm{ft}^{2}$ \\
\hline & $80 \mathrm{US} \$ / \mathrm{m}^{2}$ & 85 US $\$ / m^{2}$ & 88 US $\$ / m^{2}$ \\
\hline Unit cost & 0.23 US M\$/gpm & 0.19 US M\$/gpm & 0.25 US M\$/gpm \\
\hline Life span & $20+$ years & 20? years & 25 years \\
\hline Interest rate & 0.044 & 0.044 & 0.044 \\
\hline $\begin{array}{r}\text { Capital recovery } \\
\text { factor, } A / P\end{array}$ & 0.0762 & 0.0762 & 0.0667 \\
\hline \multirow[t]{2}{*}{$\begin{array}{r}\text { Annualized capital } \\
\text { cost }\end{array}$} & 17883 US \$/gpm-yr & 14640 US \$/gpm-yr & 17011 US \$/gpm-yr \\
\hline & 0.034 US $\$ / \mathrm{gal}$ & 0.028 US $\$ / \mathrm{gal}$ & 0.032 US \$/gal \\
\hline
\end{tabular}


Table 20 Partial cost analysis for an optimal solar and spray evaporation system.

\begin{tabular}{|c|c|}
\hline Design specs. & \\
\hline Flowrate needed & $50 \mathrm{gpm}$ \\
\hline Conceptual design & \\
\hline Spray evaporation & $7.25 \mathrm{gpm} / \mathrm{machine}$ \\
\hline & 3 machines \\
\hline & $21.75 \mathrm{gpm}$ \\
\hline +Solar evaporation & $28.25 \mathrm{gpm}$ \\
\hline & pan evaporation rate \\
\hline & $2.94 \mathrm{gpm} / \mathrm{acre}$ \\
\hline & 9.6 acres \\
\hline Capital cost & $659,324 \$$ \\
\hline Operating cost & $48,000 \$ / y r$ \\
\hline Lifespan & $10 \mathrm{yr}$ \\
\hline Interest & 0.044 \\
\hline Capital recovery factor & 0.1258 \\
\hline Annualized capital cost & $82,915 \$ / y r$ \\
\hline Annual cost & $130,915 \$ / y r$ \\
\hline & 0.005 US \$/gal \\
\hline & 4.98 US $\$ / 1000-\mathrm{gal}$ \\
\hline & 2,618 \$/gpm-yr \\
\hline Capital cost detail ... & \\
\hline Holding pond & \\
\hline earthen pond & $3,300 \quad \$$ /acre \\
\hline under-layment & 5,200 \$/acre \\
\hline liner & 11,300 \$/acre \\
\hline air roof material & $8,300 \quad \$$ /acre \\
\hline liner installation & $35,000 \$$ /acre \\
\hline supporting infastructure & $? \quad \$$ acre \\
\hline "total" cost & $63,100 \quad \$$ /acre \\
\hline Evaporative sprayer & \\
\hline Capital cost & $18,000 \$ /$ machine \\
\hline Operating cost & $16,000 \$ / \mathrm{yr}$ \\
\hline
\end{tabular}

\section{Active technologies}

Fulbright and others (1996) analyzed a number of technologies, including evaporation, for treating or managing tritiated groundwater at the SRS. A summary of their cost analysis of a direct evaporation system is provided in Table 21 . The cost is not competitive with current F- and H-area WTU operating costs, presumably due to high energy requirements of direct, single-effect, evaporation.

Several vendors were approached in this study for accurate capital and operating cost information for their respective products assuming a $25 \mathrm{gpm}$ capacity. Two vendors, Vacom and Severn Trent Services, responded with information sufficiently detailed for a comprehensive cost estimate. As shown in Table 22, total cost excluding labor is lower than current WTU costs (Table 2) for both vendors. Operator attention would be 
minimal, 2-4 hours per 24/7 week, according to Vacom. Corresponding labor requirements in the SRS environment are uncertain, but speculated to be $28 \mathrm{hrs} / \mathrm{wk}$. With the addition of labor costs, evaporation is still competitive (e.g. Vacom system).

Table 21 Cost analysis of direct evaporation by Fulbright and others (1996).

\begin{tabular}{|cl|}
\hline \multicolumn{2}{|c|}{ Fulbright and others (1996) - direct heating } \\
\hline $0.066 \$ /$ gal & total cost in 1995 dollars \\
\hline 152.4 & $1995 \mathrm{CPI}$ \\
\hline 177.1 & $2001 \mathrm{CPI}$ \\
\hline 1.16 & ratio \\
\hline $0.0767 \$ /$ gal & total cost in 2001 dollars, including labor \\
\hline 1.63 & ratio to $\mathrm{F} / \mathrm{H}$ cost \\
\hline
\end{tabular}

Table 22 Cost analyses of Vacom and Severn Trent Services evaporation systems.

\begin{tabular}{|c|c|c|c|}
\hline \multirow[t]{2}{*}{ Vacom } & \multicolumn{3}{|c|}{ Severn Trent Services } \\
\hline & capacity & $25 \mathrm{gal} / \mathrm{min}$ & capacity \\
\hline $13,140,000 \mathrm{gal} / \mathrm{yr}$ & " & $13,140,000 \mathrm{gal} / \mathrm{yr}$ & $"$ \\
\hline 900,000 & evaporator cost & 560,000 & evaporator cost \\
\hline 100,000 & dryer cost & & dryer cost \\
\hline $1,000,000 \$$ & capital cost & $560,000 \$$ & capital cost \\
\hline $76,211 \$ / y r$ & annualized capital cost & $42,678 \$ / y r$ & annualized capital cost \\
\hline $0.0058 \$ / \mathrm{gal}$ & $"$ & $0.0032 \$ / g a l$ & $"$ \\
\hline $0.0136 \$ / \mathrm{gal}$ & electric cost & $\$ / g a l$ & electric cost \\
\hline $0.0040 \$ / \mathrm{gal}$ & steam cost & $\$ / \mathrm{gal}$ & steam cost \\
\hline 0.0176 \$/gal & operating cost & $0.0200 \$ /$ gal & operating cost \\
\hline $0.0234 \$ / \mathrm{gal}$ & total cost, excluding labor & $0.0232 \$ / \mathrm{gal}$ & total cost, excluding labor \\
\hline 0.50 & ratio to $\mathrm{F} / \mathrm{H}$ & 0.50 & ratio to $\mathrm{F} / \mathrm{H}$ \\
\hline $28 \mathrm{hrs} / \mathrm{wk}$ & labor guess & $28 \mathrm{hrs} / \mathrm{wk}$ & labor guess \\
\hline $1456 \mathrm{hrs} / \mathrm{yr}$ & annual labor & $1456 \mathrm{hrs} / \mathrm{yr}$ & annual labor \\
\hline $70 \$ / \mathrm{hr}$ & labor rate & $70 \$ / \mathrm{hr}$ & labor rate \\
\hline $101920 \$ / y r$ & labor cost & $101920 \$ / y r$ & labor cost \\
\hline $0.0078 \$ / \mathrm{gal}$ & & $0.0078 \$ / \mathrm{gal}$ & \\
\hline $0.0312 \$ / \mathrm{gal}$ & total cost, including labor & $0.0310 \$ / \mathrm{gal}$ & total cost, including labor \\
\hline 0.66 & ratio to $\mathrm{F} / \mathrm{H}$ & 0.66 & ratio to $\mathrm{F} / \mathrm{H}$ \\
\hline
\end{tabular}




\section{Summary and conclusions}

Table 23 summarizes the results of the above technical and economic analyses of evaporation for treatment of contaminated groundwater.

With respect to technical feasibility, active evaporation technologies are highly reliable and robust. There appear to be no major technical barriers to using engineered evaporators for treatment of F- and $\mathrm{H}$-area groundwater. Simple, single-effect, evaporation using direct heating is not cost competitive with continued operation of the current Water Treatment Units. However, more efficient systems (e.g. Vacom product) are estimated to be somewhat more cost efficient than the WTUs. More rigorous financial analysis is needed to confirm the cost savings projected in Table 23.

Certain passive technologies appear to be technically viable in a best-estimate sense, but after considering uncertainties and a lack of field installations in the southeast US, adequate performance cannot be guaranteed with high confidence. Also, the land requirements are large. The most reliable passive technology is solar distillation, which has been field tested at large scale at several locations. Available data indicates solar distillation costs would be similar to an efficient fossil fuel driven evaporator, and less than current WTU operating costs. An optimal design combining solar pond and spray evaporation could potentially offer the least expensive alternative. However, the idea proposed herein is only in the conceptual stage and thus unproven.

The best alternative to chemical treatment of F- and H-area groundwater appears to be a two-stage system involving fossil fuel powered evaporators. The first stage would employ an efficient (e.g. multiple-effects and/or MVR) evaporator to greatly concentrate solutes (e.g. 100:1) in the feed water. The concentrate would then be fed to a flash evaporator to produce a dry ash residue of metals and non-volatile radionuclides. The low volume dry ash could then be disposed of as solid waste. Significant reductions in solid waste disposal volumes could be achieved.

Table 23 Summary of technical and economic feasibility of evaporation technologies.

\begin{tabular}{|c|c|c|c|c|c|}
\hline \multirow{2}{*}{\begin{tabular}{|c|}
$\begin{array}{c}\text { Cost } \\
\text { (\$/gal) }\end{array}$ \\
\end{tabular}} & \multirow[b]{2}{*}{$(\$ / \mathrm{kgal})$} & \multirow{2}{*}{$\begin{array}{c}\text { Reliability } \\
(1-3) \text { index }\end{array}$} & \multicolumn{2}{|r|}{ Technology } & \\
\hline & & & Class & Category & Specific \\
\hline 0.047 & 47 & 3 & Active & Chemical & F- and H- WTUs (costs for continued operation only) \\
\hline 0.077 & 77 & 3 & & Evaporation & Direct heating - Fulbright and others (1996) \\
\hline 0.031 & 31 & 3 & & & Vacom \\
\hline 0.031 & 31 & 3 & & & Severn Trent Services \\
\hline 0.030 & 30 & 2 & Passive & & Solar distillation - large scale \\
\hline $0.005+$ & 5 & 1 & & & Optimal solar and spray evaporation concept \\
\hline
\end{tabular}




\section{References}

Bibler, J. P., 1990, F/H area ground water remediation technology, Savannah River Technology Center interoffice memorandum IWT-LWP-90-0021, March 13.

Kreith, F., and J. F. Kreider, 1978, Principles of solar engineering, Hemisphere Publishing, Washington and McGraw-Hill, New York.

Fetter, C. W., 1988, Applied hydrogeology, 2nd edition, Macmillan, New York.

Fulbright, H. H., A. L. Schwirian-Spann, K. M. Jerome, B. B. Looney and V. Van Brunt, 1996, Status and practicality of detritiation and tritium reduction strategies for environmental remediation, WSRC-RP-96-0075, Rev. 0.

McCluney, W. R., 1984, Solar distillation of water, Florida Solar Energy Center, Energy Note FSEC-EN-3-80. 